\title{
Mélanges and broken formations at the boundary zone of the Magura and Silesian nappes (Gorlice area, Polish Outer Carpathians) - a result of sedimentary and tectonic processes
}

\author{
Krzysztof STARZEC ${ }^{1, *}$, Ewa MALATA ${ }^{2}$, Aneta WRONKA $^{1}$ and Luiza MALINA ${ }^{1}$ \\ 1 Geokrak sp. z o.o., Mazowiecka 21, 30-019 Kraków, Poland \\ 2 Jagiellonian University, Institute of Geological Sciences, Oleandry 2a, 30-063 Kraków, Poland
}

Starzec, K., Malata, E., Wronka, A., Malina, L., 2015. Mélanges and broken formations at the boundary zone of the Magura and Silesian nappes (Gorlice area, Polish Outer Carpathians) - a result of sedimentary and tectonic processes. Geological Quarterly, 59 (1): 169-178, doi: 10.7306/gq.1273

\begin{abstract}
Based on geological field mapping, analyses of cores from explanatory boreholes, and foraminiferal age control data, we have differentiated four types of mélanges and broken formations at the bordering zone between the Magura and Silesian nappes (Gorlice area in the Polish Outer Carpathians). These mélanges and broken formations differ in composition and structure due to different settings and processes of their formation. Several levels of broken formations within the uppermost part of the Krosno Beds were formed as mass-transport deposits at the southern slope of the Silesian Basin. They may record tectonic pulses related to advancing accretionary wedge within Magura area and directly predate the stage of the larger-scale sedimentary mélange formation at the front of the wedge. This mélange is composed mainly of the material representing the Magura succession (Siary Subunit) and the Krosno type sediments of the Silesian succession. It was emplaced within the Silesian Basin in the Early Miocene time. The so-called "Harklowa peninsula", whose geological structure has been the subject of discussions and various interpretations in the past years, is built of this type of mélange. The other recognized type of broken formation and mélange represents the chaotic bodies of tectonic origin formed at the base of the Magura Nappe.The results of our studies contribute to better understanding of the structural evolution of this part of the Outer Carpathians.
\end{abstract}

Key words: tectonic and sedimentary mélange, broken formation, accretionary wedge, Outer Carpathians, foraminifera, Early Miocene.

\section{INTRODUCTION}

Chaotic rock bodies characterized by disorganized internal structure and named most commonly as mélange or olistostrome have been the subject of many studies. Several other terms, such as wildflysch (e.g., Bird, 1969; Behr et al., 1982), megabreccias (e.g., Di Stefano et al., 1996; Bosellini, 1998), broken formation (e.g., Hsü, 1968; Codegone et al., 2011), argille scagliose (e.g., Ogniben, 1953; De Libero, 1998; Pini et al., 2004), tectonosomes (Pini, 1999) or mud volcanoes (Camerlenghi and Pini, 2009) have been used to designate chaotic deposits. These various terms refer to deposits that lie within a continuum ranging from stratigraphically coherent units (formations) to chaotic (fragmented and mixed) masses of rocks lacking stratal continuity and containing exotic blocks (Raymond, 1984). The final stage of the continuum is charac-

\section{* Corresponding author, e-mail: krzysztof.starzec@geokrak.pl}

Received: January 8, 2014; accepted: June 11, 2014; first published online: June 13, 2014 terized by the block-in-matrix fabric which means that a variety of blocks of different sizes, lithologies, and ages are randomly distributed in a muddy-sandy matrix. The intermediate stage between formation and block-in-matrix rock is represented by disrupted units in which the primary strata sequence can be still recognized.

Since the widespread use of the terms mélange and olistostrome (Bailey and McCallien, 1950, 1953; Hsü, 1968, 1974), their definition and the origin (tectonic vs sedimentary) have been a subject of debate. Over decades, knowledge on chaotic deposits has been summarized in several publications, and many classifications or definitions have been provided (e.g., Silver and Beutner, 1980; Raymond, 1984; Cowan, 1985; Sengör, 2003; Festa et al., 2010a, b, 2012; Wakabayashi, 2011). Festa et al. (2010a, b, 2012) presented a very broad overview of the mélange concept and give a redefinition and new classification of mélanges and related rock units. In our paper we follow the definitions presented by Festa et al. (2012). These authors argue that the term mélange should be used only in a descriptive meaning as suggested by Berkland et al. (1972), Silver and Beutner (1980), Raymond (1984), Cowan (1985), Wakabayashi (2011) or Wakabayashi and Dilek (2011), instead of genetic definitions such as those of Hsü (1968), Cowan (1974), Gansser (1974) or Sengör (2003) that restricted the term only to 
chaotic rocks originated by tectonic strain. Mélange, therefore, is a body of internally disrupted and mixed blocks of different rocks embedded in a pervasively deformed matrix, a body that is mappable at $1: 25,000$ or smaller scale. Blocks contained in mélange have twofold nature: primary when they are derived from the same stratigraphic units as that of the matrix or exotic when they represent different units and/or depositional environments. The nature of the blocks is a distinguishing feature between mélange and a broken formation (also "type I mélanges" according to Lash, 1987 or "tectonosomes" by Pini, 1999). The latter (sensu Hsü, 1968) is defined as a chaotic rock body in which the blocks and matrix are of the same origin. Such definitions of mélange and broken formation do not imply any process of their origin, i.e. tectonic or sedimentary.

It is widely accepted that one, or a combination, of the following processes lead to stratal disruption and to mixing of originally coherent rock sequences, i.e. tectonic deformation, sedimentary transport and deposition as well as shale diapirism:

- tectonic mechanisms such as faulting, folding, shearing or thrusting can form mélanges at great depths as well as near the surface and the style and degree of rock deformations are strongly related to the depth (e.g., Festa et al., 2012). Brittle or semi-brittle deformation becomes gradually replaced downward by ductile deformations. Generally, tectonic mélanges display several structures characteristic of other rocks developed in fault or shear zones (Needham and Mackenzie, 1988), e.g. at shallow structural levels commonly pinch-and-swell and boudinage structures are formed in sandstones and scaly fabric in claystone/mudstone layers, while mélanges originating in shear zones contain mostly lozenge- to sigmoidal-shaped blocks;

- sedimentary mass transport processes are considered to be more efficient for stratal disruption at shallow structural levels than tectonics (Festa et al., 2012). Mixing of rocks results from gravity driven transport in slumps, slides or debris flows. Sedimentary processes produce a broad spectrum of chaotic rocks, ranging from folded and boudinaged rock sequences, which partly retain the original succession, to completely disintegrated and mixed masses, i.e. block-in-matrix rocks (Ogata et al., 2012);

- mud or shale diapirism is caused by fluid overpressure that leads to the rising of mostly muddy material from depth towards the sea-floor. By intruding the overlying and underlying rocks the material forms a diapiric body or mud volcanoes, often with characteristic structure, e.g. well-developed scaly fabric at the diapir boundaries and poorly developed foliation in the centre of the diapiric mélange (Barber and Brown, 1988; Orange, 1990; Kopf, 2002; Camerlenghi and Pini, 2009).

Deposits classified as slumps, olistostromes or debris flow sediments have been recorded from the Carpathians by several authors (e.g., Ksią kiewicz, 1958; Ślączka, 1961; Ślączka and Wieser, 1962; Cieszkowski et al., 1987; Oszczypko and Ślączka, 1987; Cieszkowski and Polak, 1998; Słomka, 2001; Strzeboński, 2005) but they occurred on a small scale, usually as one or a few layers, forming interbeddings within the "normal" turbidite succession. In the sixties and seventies a few papers were published in which rock bodies of considerable sizes, fulfilling the mélange definition, were described (Jasionowicz and Szymakowska, 1963; Szymakowska, 1976; Sikora and Szymakowska, 1977; Połtowicz, 1978). More systematic studies focused on chaotic rocks have been performed during the last 15 years (Jankowski, 1997a, 2000, 2007; Cieszkowski et al., 2009, 2012; Ślączka et al., 2012).

This paper concerns the chaotic deposits in the Gorlice region that were previously recognized by Jankowski (1997a, $2000,2007)$ and whose origin and geological character were variously interpreted (see below). Due to generally small and poorly exposed outcrops in the Outer Carpathians, the identification of chaotic rock bodies is quite difficult. During our mapping work, which besides standard field study of outcrops included also drilling of a series of shallow exploratory boreholes within poorly exposed areas, comprehensive data were collected. The field material together with very detailed micropalaeontological analyses allow for the differentiation of several types of mélanges and broken formations. Recognition of the processes of mélange formation and identification of their position within an accretionary wedge are highly important to increase our understanding of the evolutionary history of the Carpathians.

\section{REGIONAL SETTING AND HISTORICAL BACKGROUND}

The study area is situated in the central part of the Polish Outer Carpathians that belong to the Carpathian Mountain system, stretching in a form of the $1300 \mathrm{~km}$ long arc. Together with the Alps in the south-west and the Dinarides in the south-east, the Carpathians form an orogenic belt surrounding the Pannonian Basin. The Carpathians are divided into two zones: the Inner and Outer Carpathians (Ksia kiewicz, 1977). The latter developed from the southern margin of the Northern European Plate (Sikora, 1976). The disintegration of the passive margin of this plate led to the development of the basin system in the Middle/Late Jurassic (e.g., Oszczypko, 2004, 2006). This was followed by subduction of the European Plate margins below the advancing Inner Carpathians and as a result of tectonic off-scraping an accretionary wedge was developed from the sediment infill of the Outer Carpathian basins. Folding of the Outer Carpathians was initiated at the end of the Paleocene at their inner parts and was completed during the Early Burdigalian (e.g., Nemčok et al., 2006a, b; Oszczypko, 2006). During Early and Middle Miocene the Carpathian Foredeep developed in front of the advancing Carpathian orogenic wedge (Oszczypko, 1998; Oszczypko et al., 2006).

The Outer Carpathian fold-and-thrust belt consists of several nappes (units) sheared off from the basement. These nappes are thrust upon each other, and are overthrust towards the north onto the Miocene Foredeep and its pre-Miocene platform basement. In the Polish Outer Carpathians three main groups of nappes are traditionally distinguished (Ksia kiewicz, 1977; Oszczypko, 2006). The Magura group in the south (Late Oligocene/Early Miocene accretionary wedge) is the innermost and largest tectonic unit of the Western Carpathians (Oszczypko, 1992). It is flatly overthrust onto the middle group (Early/Middle Miocene accretionary wedge) which consists of several units: the Fore-Magura-Dukla group, Silesian, SubSilesian and Skole units. The Marginal Group includes folded Miocene rocks (Fig. 1). It is generally accepted that the sedimentary succession of each tectonic unit was formed in separate sedimentary basins.

The area of our studies comprises both the marginal part of the Magura Nappe, belonging to the so-called Siary Subunit and the most southern part of the Silesian Nappe represented by the Gorlice Fold structure. In the area of our studies the Siary Subunit includes rocks ranging in age from the Upper Cretaceous (Ropianka Formation) to Lower-Middle Eocene (Łabowa Formation), whereas the Lower Oligocene sandstones of the Magura Beds occur only as blocks within chaotic deposits (Fig. 2). The Gorlice Fold is built of rocks representing the upper part of the Silesian succession (Fig. 2) with the Lower Istebna Beds (Upper Cretaceous) exposed in the hinge of the fold. The south- 


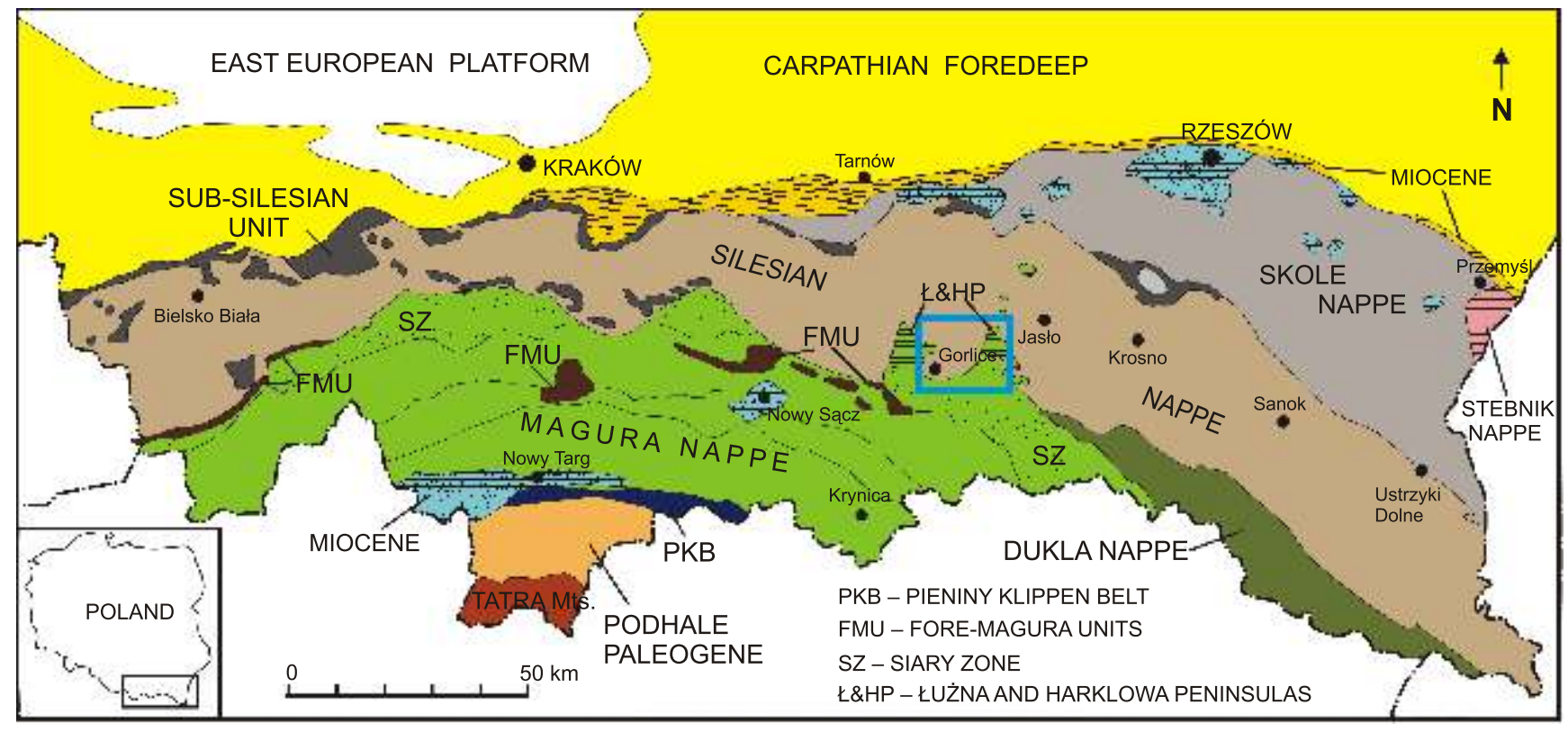

Fig. 1. Tectonic sketch of the Polish Outer Carpathians (after ytko et al., 1989, modified) with the studied area marked with a blue rectangle

The sketch shows the most common view according to which the $Ł u$ na and Harklowa peninsulas and the outliers (marked with stripes), lying north of them, belong to the Magura Nappe

ern limb is built of successively younger formations up to the Oligocene Krosno Beds, while the northern limb is completely reduced and the fold is sliced to the north.

Several different opinions have appeared on the geology of the studied area since 1930-ties. According to one of the most common views (Figs. 1 and $3 A$ ) the Magura Nappe forms two narrow tongues, protruding to the north, traditionally named "Łu na and Harklowa peninsulas". Moreover, on the extension of the "Harklowa peninsula" several so-called outliers occur. They represent the northernmost remnants of the Magura Nappe cover, i.e. tectonic islands, which were preserved from erosion due to their emplacement within the synclinal zones of the Silesian Unit. Such an explanation was proposed by Pazdro (1934) and Świdziński (1934). Additionally, the first author included the peninsulas and outliers into another distinguished zone (the Harklowa zone) in order to emphasise their facial individuality from the more southern Magura zone, i.e. the Siary Subunit (Świdziński, 1953, 1958). This concept was subsequently visualized in the Detailed Geological Map of Poland, in 1:50,000 scale, edited by the Geological Institute (Gorlice sheet - Sikora, 1964; Rzepiennik sheet - Koszarski, 1966-1967; Jasło sheet - Koszarski and ytko, 1966-1967; Osiek sheet Koszarski and Tokarski, 1965-1967) and this view became commonly accepted in the Carpathian literature, applied in geological maps or general sketches (e.g., Ksia kiewicz, 1962;

ytko et al., 1989; Nescieruk et al., 1995-1996; Oszczypko et al., 2005; Zuchiewicz and Oszczypko, 2008).

This area had been the subject of earlier studies by Tołwiński (1921) who included it into a new unit so called "Jasło Nappe", lying on the Silesian Nappe and covered by the Magura succession. This idea was subsequently developed by Koszarski and Koszarski (1985) and Koszarski (1999). According to these authors the Jasło Nappe represents a continuous flysch succession of the Paleogene to Lower Miocene deposits. The lithostratigraphic sequence displays some similarities to both the Siary Subunit (Magura Nappe) as well as to the more northern units - the Grybów and Dukla ones. The similarities of the Paleocene and Eocene deposits to those of the Siary Subunit is additionally emphasised by the same palaeotransport directions (i.e. from the north). This situation changed in the Early Oligocene when the Jasło zone was isolated from the Siary zone due to development of "the Fore-Magura upheaval" (sensu Koszarski, 1999) and connected with Fore-Magura facial zone. Sedimentary succession of the Jasło Nappe includes several olistostrome levels within the Late Eocene-Oligocene interval. During the orogeny phase the Jasło zone was thrust together with the Magura Nappe to the north onto the Silesian Unit. This view was adopted by Oszczypko et al. (2008) and elaźniewicz et al. (2011) in their proposal of tectonic regionalization of Poland.

Jasionowicz and Szymakowska (1963) presented convincing evidence that the outliers were displaced into their present position as a consequence of gravitational slides of rock masses detached at the front of the overthrusting Magura Nappe. This took place during the final phase of the Krosno facies sedimentation in the Silesian Basin. Transversal depression within the Silesian Basin enabled the Magura Nappe to enter the basin forming a peninsula. Subsequently, the peninsula became a source of material, from which blocks of the Magura rocks were detached, slid along slopes, and came to rest within the Silesian Basin. The material finally was preserved as outliers. The above-mentioned authors suggested that the origin of outliers was similar to the argille scagliose of the Apennine Mountains. However, Szymakowska (1966) changed her view and stated that the outliers both from a lithostratigraphic and tectonic point of view belonged to the Fore-Magura Zone, thus their current character and position was a result of tectonics and not a sedimentary process. Then Szymakowska (1976; Sikora and Szymakowska, 1977) again advocated for the sedimentary origin of the outliers defining them as olistostromes formed under marine conditions as a result of sliding of rock masses and subsequent transportation in mud gravel flows. An Early Mio- 

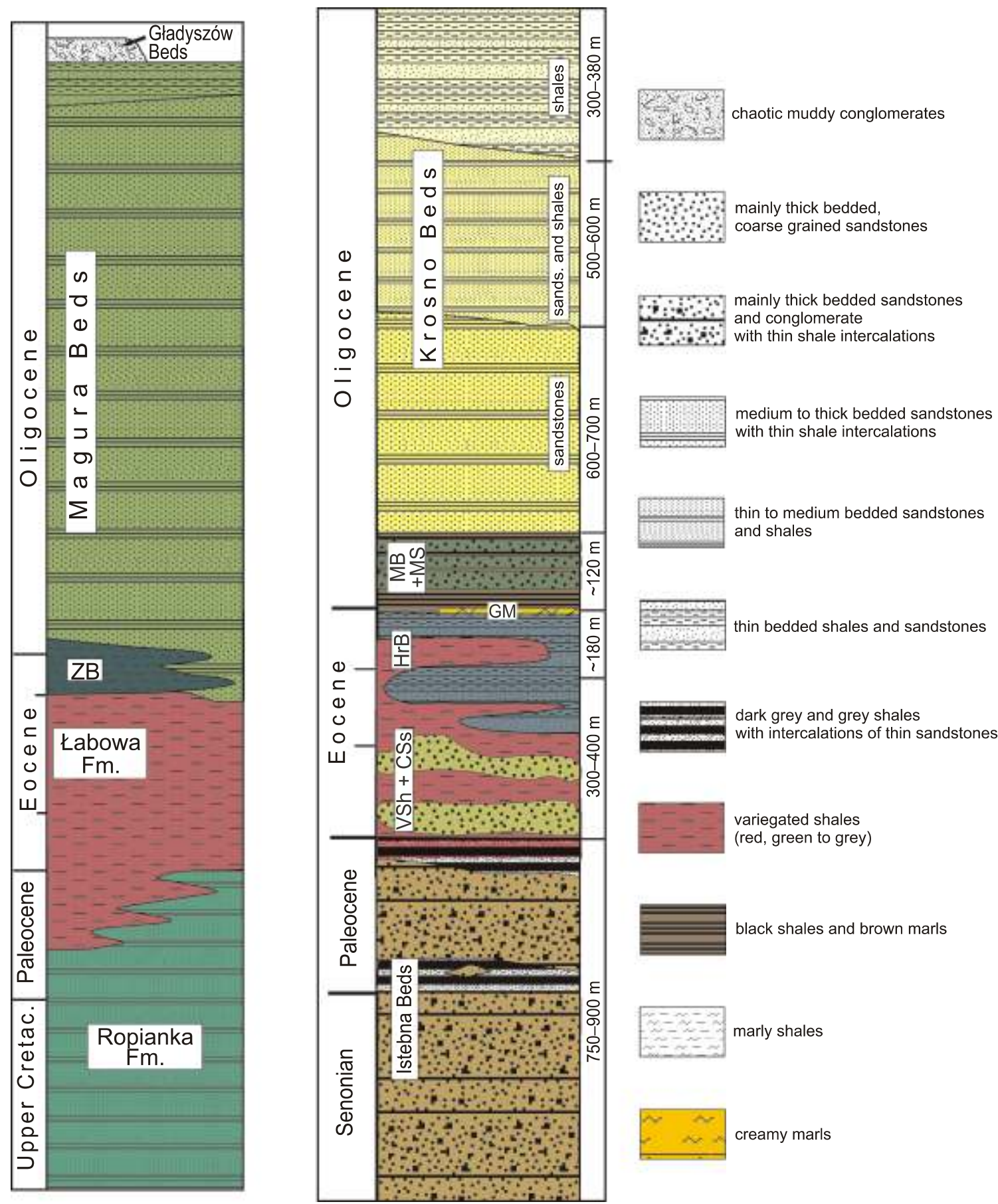

Fig. 2. Lithostratigraphic scheme and facies of the northern part of the Magura succession, i.e. Siary Subunit (left), and the Silesian succession (right)

Magura succession: ZB - Zembrzyce Beds/Sub-Magura Beds/Szymbark Shales; Silesian succession: VSh + CSs - Variegated Shales and Cię kowice Sandstones, HrB - Hieroglyphic Beds, GM - Globigerina Marls, MB + MS - Menilite Beds and Magdalena Sandstones; based on field studies supplemented by biostratigraphical data presented by Malata (1981), Kopciowski and Garecka (1996), Oszczypko-Clowes (2001), Gedl and Leszczyński (2005)

cene (Helvetian) age of the olistostromes was recorded in several samples (Szymakowska, 1976). Despite the above interpretations, in the Jasło sheet of the Detailed Geological Map of Poland in 1:50,000 scale co-authored by Szymakowska (Wójcik et al., 1992) the outliers are presented as remnants of the Magura Nappe, thus implying their tectonic origin.
More recently, Jankowski (1997a, b, 2000, 2007) proposed another explanation. His mapping works within the " $€ u$ na and Harklowa peninsulas" led him to the conclusion that they are built of chaotic complex of block-in-matrix type and distinguished them as a separate formation called the Gorlice Beds (Jankowski, 1997a, b; Kopciowski et al., 1997a, b). These beds 


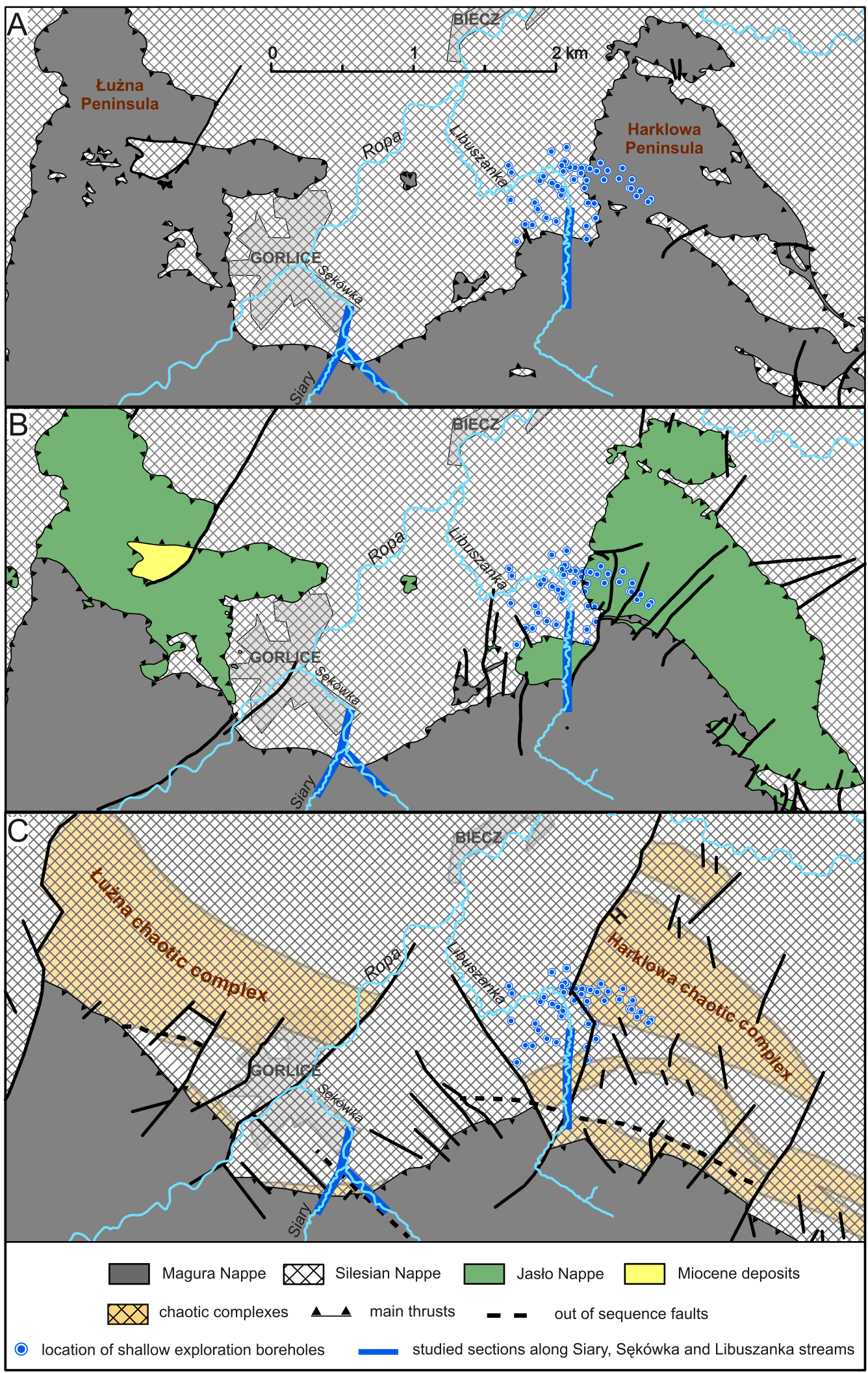

Fig. 3. Simplified tectonic sketches showing three different interpretations of geology of the studied area

A - Łu na and Harklowa areas as tectonic peninsulas of the Magura Nappe (based on Detailed Geological Map of Poland, for references see the text); B - peninsulas as separate tectonic unit, i.e. Jasło Nappe (based on Koszarski, 2001); C - peninsulas as chaotic complexes within the Silesian succession (based on Jankowski, 2007) 


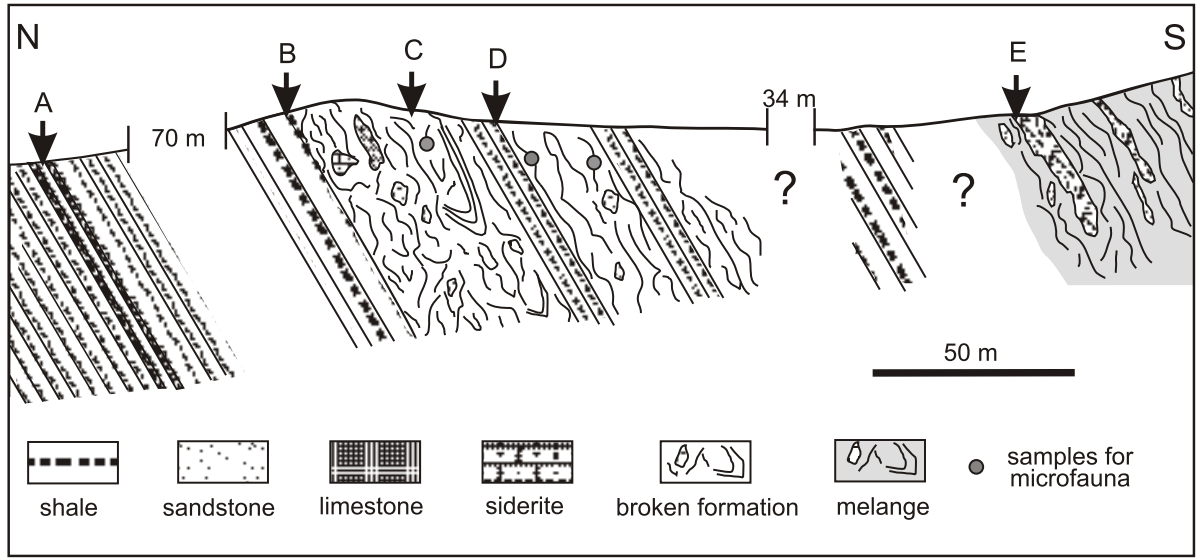

Fig. 4. Schematic sketch showing sections outcropped along the Siary Stream (vertically not to scale)

A - Upper Krosno Beds with Jasło Limestones (Fig. 5); B - boundary between coherent layers of Krosno shales and the first interval of BrFm1 (Fig. 6A, B); C - chaotic internal structure of BrFm1 (Fig. 6C-F); D - boundary between regularly bedded Krosno shales and the upper interval of BrFm1 (Fig. 6G); E - mélange (Me1) composed of rocks belonging to Ropianka and Łabowa formations Me1 (Fig. 7A, C)
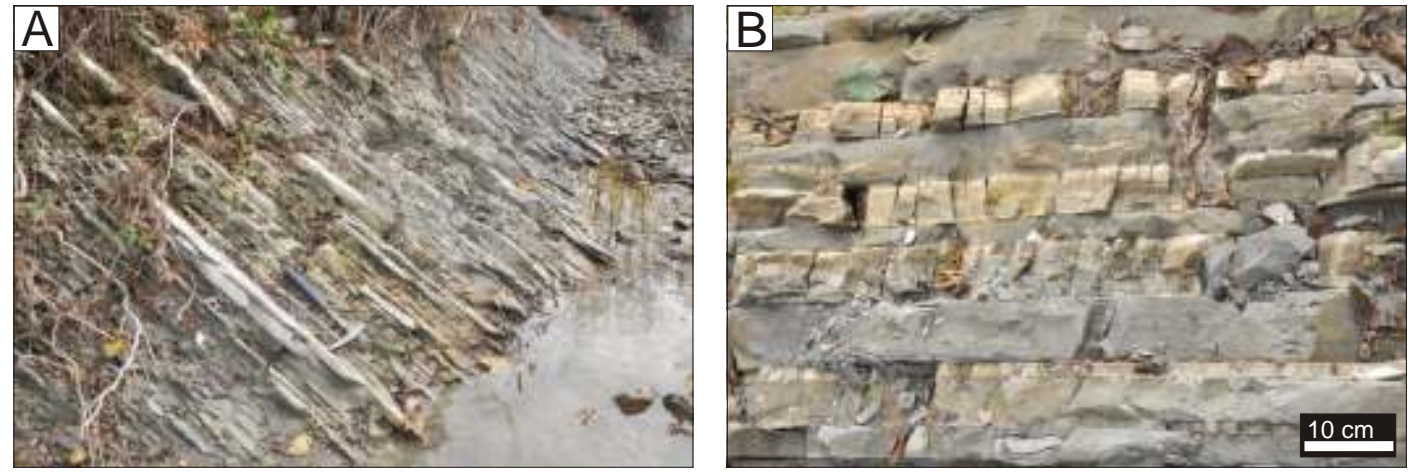

Fig. 5A - sequence of thin-bedded shales rarely intercalated by thin layers of sandstones, representing the uppermost part of Krosno Beds (Siary Stream); B - layers of Jasło Limestones horizon

emphasised by plant detritus. The thickness of layers ranges from a few to $30 \mathrm{~cm}$. The sandstones are represented by thin and very thin beds, usually of a thickness smaller than the accompanying shales. They are fine-grained, calcareous, displaying light grey or blue-grey colours. The beds usually show the Tcd subdivisions, their soles are flat, rarely covered with current marks or bioturbation structures. The sandstone to shale ratio is close to $1: 9$.

Within a few metre interval of these beds several layers of the Jasło Limestones occur (Fig. 5B), i.e. beige, yellowish, massive or parallel laminated limestones (compare to Haczewski, 1989). The thickness of the limestone layers usually does not exceed $5 \mathrm{~cm}$. The Jasło Limestones are one of the most important regional marker horizons within the Oligocene succession of the Silesian Unit (e.g., Koszarski and ytko, 1961; Jucha, 1969; Haczewski, 1989; Ciurej and Haczewski, 2012). Almost the entire succession of the Krosno Beds lies below this horizon, therefore it can be assumed that the studied Krosno section represents only the Oligocene age (Garecka and Olszewska, 1998).

Almost 100 metres above the limestone horizon in the Siary Stream the rhythmically alternating beds of grey shales pass into a chaotic rock body that is distinguished herein as a type 1 broken formation (BrFm1; Figs. 4 and 6A). The top surface of the coherent shaly sequence is flat and displays sharp boundary with the broken formation, although the boundary is not easily visible in the outcrop because the broken formation is lithologically similar to the sediments of the underlying coherent succession (Fig. 6B). The main features of the BrFm1 are as follows:

- composition: matrix consists of grey muddy sediment, calcareous and abundant in muscovite flakes. Blocks include fine-grained sandstones, grey in colour, calcareous and rich in mica, packets of thin-bedded sandstones and shales or only shales, and a few blocks of grey dolomite yellowish on surface, commonly described in the Carpathian literature as siderites;

- provenance: all the blocks have native (non-exotic) character with respect to the matrix, and both blocks and matrix are similar to typical components of the Upper Krosno Beds;

- styles of blocks: blocks range in size from several centimetres to over one metre (Fig. 6C-F). They are angular to sub-rounded, smaller ones are often strongly contorted, U-shaped and ribbon-like forms also occur (Fig. 6D-F). Some of the sandstone blocks reveal internal distortions. Their original 
are composed of green, grey to black claystones or clayey shales that form the matrix of a chaotic body with blocks of various rock types and sizes. The blocks are delivered mainly from the flysch formations of the Magura, Dukla and Silesian successions, moreover blocks of limestone and metamorphic rocks are also present. The Gorlice Beds cover the whole area of peninsulas and outliers (Fig. 3C), and they are also recognized in other parts of the Carpathians (Jankowski et al., 2004). They comprise chaotic rock units of different origin, i.e. olistostromes, mélanges and broken formations (Jankowski, 2007, uses the genetic definitions of these terms), thus part of them represent tectonic mélanges associated mainly with out of sequence faults, whereas others are of sedimentary origin. They are not differentiated in the maps (Fig. 3; Jankowski et al., 2004; Jankowski, 2007) however, particularly for the peninsulas and outliers Jankowski (2007) proposed slumping from an active slope or slumping from an active fault scar in order to explain their origin. On the basis of documented microfauna from the matrix of chaotic deposits, he implied an Early Miocene age of the peninsulas' olistostrome. As a result the chaotic rock units form the uppermost part of the Silesian succession. Recently, the olistostromal nature of the peninsulas has been also suggested by Cieszkowski et al. (2009, 2012).

\section{METHODS AND MATERIALS}

This paper is based on the data gathered during geological mapping of the $70 \mathrm{~km}^{2}$ area eastward of Gorlice town. The field work and update of the geologic map have been carried out by a team of Geokrak Company in framework of a project for RWE Dea. A classic surface geological mapping in 1:10,000 scale, including standard macroscopic description of outcrops and stratigraphic-structural observations, with the use of modern techniques (GPS, GIS software), has been conducted. Moreover, logging of well-exposed successions, along three streams has been performed (Fig. 3) and outcrops of chaotic deposits have been studied in detail.

Almost fifty shallow boreholes have been drilled in the area studied. They were situated in the southwestern part and eastward of the "Harklowa peninsula" (Fig. 3). The drilling work has aimed at determination of the character of rocks and their lithostratigraphy and has been a supplementary method to field mapping as the number of natural outcrops in the area described are very limited due the considerable cover of the Quaternary deposits. The exploration boreholes were drilled and cored using a Geotoo/RHB GTR 780 mechanical rotary device. In the near surface zone, the boreholes were drilled with a $90 \mathrm{~mm}$ flight auger bit. In a cored interval a double core barrel with an outer diameter of $66 \mathrm{~mm}$ was used. Water-based mud has been used for core intervals. Basic macroscopic description was conducted in the field, and then followed by detailed studies of cores and cutting samples in the Geokrak Ltd laboratory, i.e. description of lithology and sedimentary structures and micropalaeontological analyses.

Of 44 samples examined for foraminiferal content, 20 were collected from cores, 19 from drill cuttings recovered from 13 boreholes, located in the SW part of the "Harklowa peninsula" and from a borehole located in the Silesian Nappe (Fig. 3). An additional five samples were collected from two outcrop sections along Siary and Libuszanka streams (Fig. 3).

Samples were disintegrated by a repeated freeze-thaw method, using a saturated solution of sodium sulphate $\left[\mathrm{Na}_{2} \mathrm{SO}_{4} \times 10 \mathrm{H}_{2} \mathrm{O}\right]$ and then washed over a $63 \mu \mathrm{m}$ screen and dried out. Residues were sieved into a few fractions
$(>0.063 \mathrm{~mm})$ and each fraction was picked separately in conventional manner. The samples were not quantitatively analysed, however, in those poor in foraminifera the whole residue was checked, while in the others a sufficient number of foraminifera was picked to determine their biostratigraphy.

SEM images of the most characteristic or important for age determination foraminifera were made using the Hitachi S-4700 Scanning Microscope at the Institute of Geological Sciences of the Jagiellonian University and two species were photographed using a Sony (A330) digital camera mounted on a Nikon SMZ1500 stereomicroscope.

\section{RESULTS}

\section{FIELD OBSERVATIONS}

Deposits of chaotic structure are exposed in the transition zone between the Silesian and Magura units. Relatively good outcrops can be observed along three streams, i.e. the Siary, Sękówka and Libuszanka streams (Fig. 3). Along the Sękówka Stream, between Gorlice town and Sękowa village, the upper part of the Silesian succession is exposed, starting from the Hieroglyphic Beds, through the Menilite Beds with the Magdalena Sandstones, to the Krosno Beds which are subdivided into three parts: the Lower Krosno Beds composed of thick bedded sandstones, a middle part with thin to medium sandstone shale layers, and the upper part dominated by thin beds of shales (Fig. 2). This Eocene-Oligocene succession forms the southern limb of the Gorlice Fold. The strata dip normally to the south at relatively steep angle between 50 to $65^{\circ}$. Exposures along the Siary Stream, which is a tributary of the Sękówka Stream, embrace the middle and upper part of the Krosno Beds. Further south, along both streams, deposits of the Ropianka Formation are exposed. At the initial zone they are strongly deformed, whereas to the south they pass into the "normal" sandstone-shale succession dipping to the south. The Ropianka Formation forms the marginal part of the Magura Nappe in the studied area. According to the borehole data (the "Gorlice 12" borehole) the Magura cover is relatively thin within its border zone which implies a rather flat thrust onto the Silesian Krosno Beds (Konarski, 1980, 1986; Jankowski, 2000).

The situation in the eastern part of the area in question is slightly different. Along the Libuszanka Stream the Hieroglyphic, Menilite and Krosno beds, are exposed, although only the lower and middle part of the latter unit is represented. The Krosno-type strata generally dip to the south-east and are cut by numerous faults, usually characterized by minor displacement (up to $4 \mathrm{~m}$ ). The Middle Krosno Beds are followed by deposits of undoubtedly Magura provenance, defined herein as mélange, whereas previously these were variously interpreted, i.e. as the variegated shales of the Magura Nappe (Koszarski and Tokarski, 1965-1967), part of the separate Jasło Nappe succession (Koszarski, 2001) or a chaotic rock body of the Gorlice Beds within the Silesian Unit (Jankowski, 2007).

Siary and Sękówka streams. In the transition zone between the Magura and Silesian units the streams flow almost parallel, about $3 \mathrm{~km}$ apart. Their directions are approximately perpendicular to the strike of both the Magura and Silesian strata.

Starting from the uppermost part of the Krosno Beds, marly shales/mudstones intercalated by thin sandstones can be observed in banks of both streams (Figs. 4 and 5). Shales are mainly steel-grey and greenish-grey, calcareous and rich in mica minerals. Silty shales are often parallel laminated, 

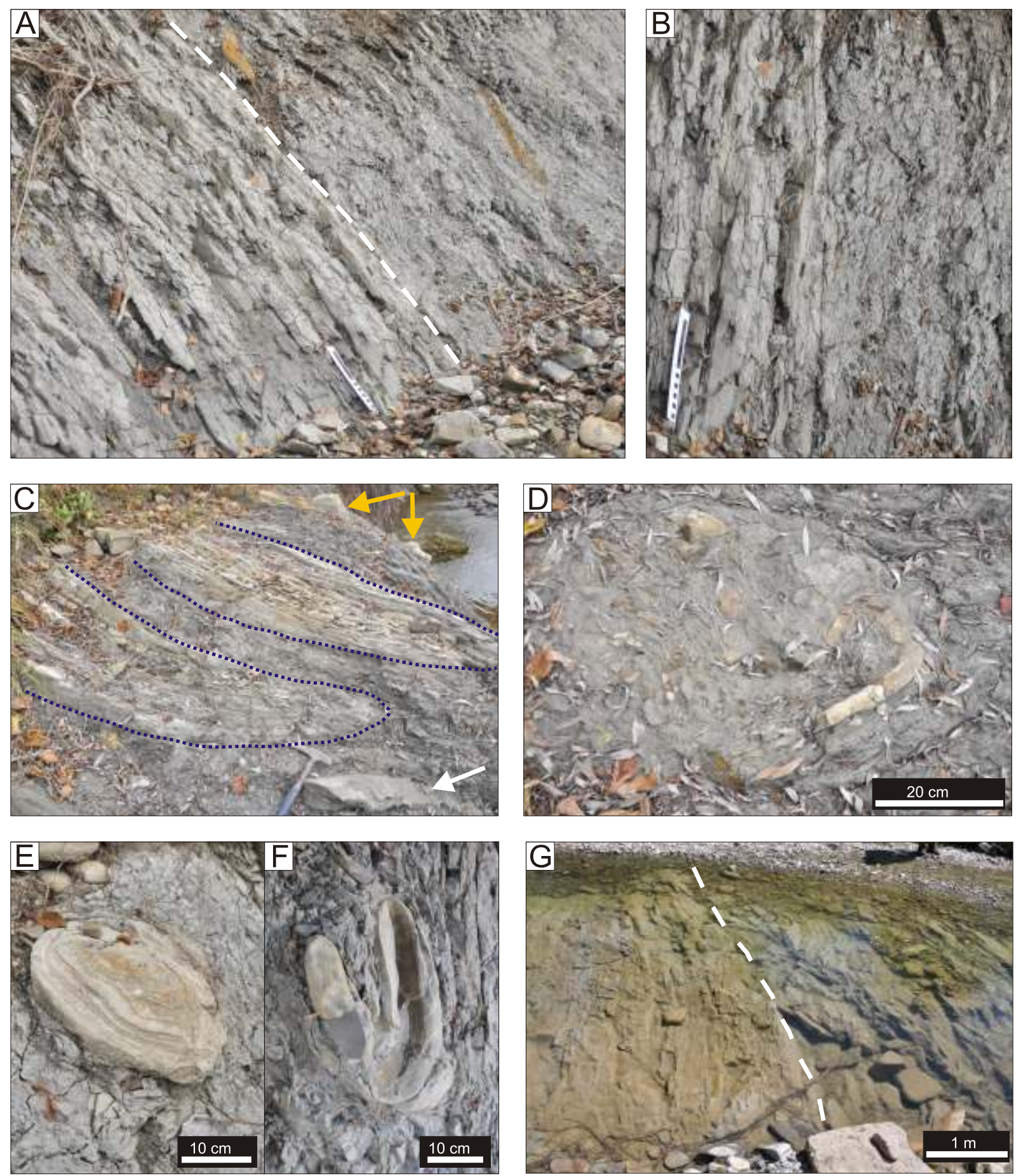

Fig. 6. Examples of the broken formation within the Krosno Beds succession

A - boundary between regularly bedded shales and the base of chaotic body (BrFm1), $20 \mathrm{~cm}$ scale at the bottom of outcrop; $\mathbf{B}$ close-up of $\mathrm{A} ; \mathrm{C}$ - view of BrFm1 two folded packets of thin layers separated by muddy matrix, isolated block of sandstone (white arrow) and siderite (yellow arrows); $\mathbf{D}-\mathbf{F}$ - details of BrFm1 showing strongly contorted, ribbon-like fragments of thin sandstone layers, internally deformed, convoluted sandstone clast and U-shaped siderite fragment, respectively, that are embedded in isotropic muddy matrix; $\mathbf{G}$ - contact of several metres thick coherent shale packet with the second interval of BrFm1 (outcrop at the bottom of the stream)

sedimentary structures are obliterated probably because of liquefaction, suggesting that the deformation mostly occurred in wet, non- or partly consolidated rocks (Fig. 6E). Blocks of thin sandstones and shales, in which the coherent stratigraphic bedding is still partially preserved, form steeply inclined tight folds of slightly curving axis plane (Fig. 6C). The fold axes as well as the longest axes of the larger sandstone blocks are almost parallel to the bedding surface of the underlying shales;

- fabric of matrix: matrix has a brecciated texture that is characterized by the presence of millimetre to sub-millimetre size clasts of claystone and sandstone within muddy bulk; 
- matrix: block ratio and relationship - matrix forms the main bulk of the broken formation, although distinction between shale blocks and matrix is, to some extent, difficult - shale borders are indistinct and they smoothly pass into matrix. Blocks are randomly distributed within matrix.

The thickness of the broken formation body is $37 \mathrm{~m}$. It lies concordantly on the coherent shaly succession and is covered by a six metre thick packet of grey shales, which displays the same character as the succession (Figs. 4 and 6G). The shale beds in the packet are aligned parallel to bedding in the underlying coherent sedimentary layers. The packet is, in turn, overlain by another internally folded and disrupted body of grey calcareous shales that repents the same type of broken formation (Figs. 4 and 6G). The upper interval of the broken formation is at least 17 h thick, followed by a subsequent packet of regularly bedded shale layers, although the boundary between them is not exposed. Further to the south along the stream, a few, about 0.5 to $2 \mathrm{~m}$ thick sections of the Krosno type shales, coherent or disrupted, occur, thus the real nature of the uppermost part of the Krosno succession is difficult to define. It seems that at least one additional interval of broken formation (BrFm1) is present within the succession, in addition to two ones described above (Fig. 4).

Along the Sękówka Stream only one outcrop of BrFm1 occurs about $70 \mathrm{~m}$ above the Jasło Limestones horizon. The outcrop is quite small (about $2 \mathrm{~m}$ long in the western stream bank), moreover neither the lower nor the upper contact of this chaotic body is exposed, therefore it does not provide a good material for detailed study. Nevertheless, it can be assumed that the outcrop is a continuation of the one occurring in the Siary Stream, due to its similar structure and lithology. The BrFm1 forms a chaotic rock body or rather a few bodies separated by packets of rhythmically bedded shales that stretch latitudinally in accordance with the strike of the turbidite strata of the Krosno Bed succession.

Another type of a chaotic rock body can be observed more to the south, in the area assigned either to the Ropianka Formation (formerly known ss meds) of the Magura Nappe Sikora, 1970; Koszarski,2001) or the chaotic complex of the Gorlice Beds (Jankowski, 1997a, 2007; Kopciowski et al. 1997b). \$everal outcrops along both streams, provide initormathe character of these rocks, however, the direct contact between the Ropianka type rocks and the Krosno succession is nowhere exposed. Two kinds of chaotic rocks are differentiated herein, named as type 1 mélange (Me1) and type 2 broken formation (BrFm2), which are closely related to one another. The first one occurs in the northern, relatively narrow zone, about 30-50 m in width. Features of Me1 are as follows:

- composition: matrix includes mainly green-grey or bluish-grey shales, and subordinate brown ones, occurring in both calcareous and non-calcareous varieties. Red and green clays, clearly distinguishable from the generally grey background, can be also recognized. They are usually included in the matrix, seldom occurring as clasts reaching up to a few centimetres in diameter. Sandstones that form blocks are fine and medium grained, bluish-grey, mostly calcareous, and often with preserved sedimentary structures such as parallel, cross, or convolute bedding. Subordinately, fine-grained, light grey sandstones, strongly calcareous can be encountered, usually characterized by parallel lamination, emphasised by black plant detritus;

- provenance: most of the volume of the Me1 body consists of the Ropianka type rocks, both in the matrix as well as the clasts and blocks. Red clays may be derived from the variegated shales forming a few metre thick interval within the
Ropianka Formation or from the variegated shales of the Eocene Łabowa Formation. The light grey sandstones resemble rocks of the Krosno Beds;

- styles of blocks: sandstones occur in a form of moderately- to highly-stretched layers. The sizes of blocks are highly variable, from millimetres to metres that is strongly related to the initial thickness of sandstone layers, the longer blecks are formed by the thickest sandstones (Figs. 7A and 8A-C). Strong, layer-parallel extension result elopment of pinch-and-swell structures and necking of the layers (Figs. 7B, $\mathrm{C}$ and $8 \mathrm{~F}$ ), and brittle and/or ductile boudinage causing part or complete separation of layers (Fig. 7D). This deformation produced an alignment of the blocks and the shaly layers (i.e., the matrix) in a pseudo-bedding tashion;

- fabric of matrix: a pervapive sca y fabric is developed in the entire matrix Figs. 7C and 8B, C) i.e. the clayey matrix is deformed by anastomosing cteavage planes, which split the matrix in a millimetre to centimetre lens-shaped scales (Dellisanti, 2008). The blocks are commonly intruded by the muddy matrix (Figs. 7C a d 8D). The intruded matrix and the distribution of well-preserted sedimentary structures within the blocks indicate that the muddy material was more fluid than the sandy one during mélange formatiqn (Yamamoto et al., 2012);

- matrix - block ratio andrelationship: strongly disrupted strata of blocks in a matrix fabro (Figs. 7A and 8A-C), i.e. fragments of sandstone layers embedded within thatrix.

The mélange of block in matrix structure passing to the south takerding to the presented above definitions (Festa et al., 2012), should be classified as broken formation (BrFm2)

- composition: green-grey or bluish-grey shales and bluish-grey sandstones the same as described above;

- provenance: no exotic blocks are incorporated, only rocks of the Ropianka Formation;

- styles of blocks: slightly or not deformed decimetre to metre thick sands anors $7 \mathrm{~B}$ ) of contihuous at the scale of outcrop (Fig. 8E), in both case 3 they are usually fractured, some of them reveal pinch-and-swell structures (Fig. 8F);

- fabri申 of matrix and relationship with blocks: sandstones alternate with moderately to strongly deformed shaly interlayers of the similar thickness, that display scaly fabric and include angular or lenticular-shaped blocks of sand stone (Fig. 8E, F).

BrFm2 partly retains their original stratigraphic coherence and every th icker layer is inclined to the south. BrFm2 shows a gradual transition to normal bedded succession of the Ropianka Formation. It stretches for a distance of about $250 \mathrm{~m}$ along the Siary Stream and less than $200 \mathrm{~m}$ along the Sękówka Stream.

Libuszanka Stream. Along the Libuszanka Stream only the lower and middle part of the Krosno Beds is exposed, whereas the upper one may be either missing or covered by the chaotic deposits defined herein as type 2 mélange (Me2). The intornatrix of

- composition: matrix is a mixture of red, non-calcareous clays and bluish-grey, subordinately green clays, in some parts calcareous, in others non-calcareous (Fig. 9). The most common lithological type of blocks is a bluish-grey, fine to medium grained sandstone, usually with preserved sedimentary structures (convolute or parallel lamination), slightly celicareous, consisting of quartz, a large quantities of mica and sфme glauconite (Fig. 9A). Another type is olive-green, fine-grained sandstone, non-calcareous, rich in mica and black organid matter that is aligned along laminae (Fig. 9B). Packets of thin bedded sand- 

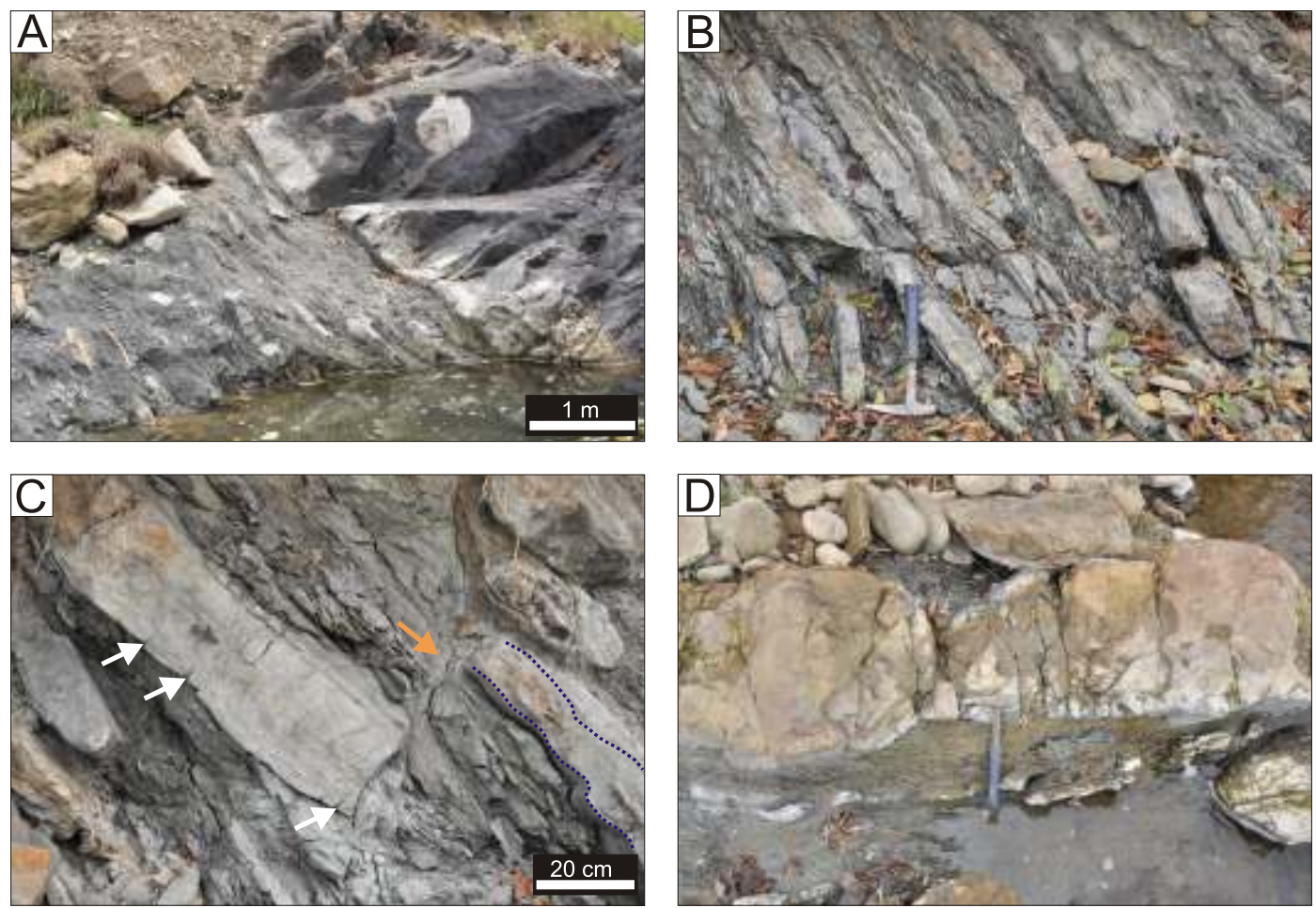

Fig. 7. Examples of mélange and broken formation within Ropianka Formation (Siary Stream)

A - mélange (Me1) characterized by block-in-matrix fabric - centimetre to decimetre angular sandstone clasts randomly included in greenish-grey shaly matrix (left side) enclosing a huge block of fractured sandstone (right side), black colour due to crude oil staining; B - progressive stratal disruption of well-bedded unit of Ropianka Formation forming broken formation (BrFm2); $\mathbf{C}$ - detail of Me1 showing Ropianka type sandstone blocks within grey shaly matrix, blocks exhibit pinch-and-swell structures (dotted lines) or initial fracturing filled by matrix (white arrows), in the central part fluidal feature deforming scaly fabric of matrix related probably to migration of overpressured fluids (yellow arrows); D - boudinaged sandstone layer wrapped by shaly matrix

stones and shales also form the bigger blocks (Fig. 9C). More over, different kinds of shales can occur as blocks, however, on a smaller scale.

- provenance: most of the sandstone blocks display resem blance to rocks of the Ropianka Formation, others can be as s gned to the Krosno Beds, clays forming matrix may be derived from both the Ropianka and Łabowa formations;

- styles of blocks: angular to subrounded hard blocks vary from a centimetre to over one metre. They usually have sharh outlines and variable shapes but often almost isometric and elongated. Sandstone-shale packets usually are strongly distorted and form tight folds that additionally are internally de formed (Fig. 9C), e.g. more competent sandstone layers are boudinaged and defragmented, whereas in shales the original layering is indistinct;

- fabric of matrix: muddy matrix is brecciated - the micro clasts are millimetre to centimetre in size and include mainly dark to light grey, red and green mudstones. They have either rounded or angular shapes;

- matrix-block ratio and relationship: relative volume of matrix fraction is about $70 \%$ or more, blocks are floated, with a random distribution, in a muddy matrix.

\section{SHALLOW BOREHOLE DATA}

Twenty one shallow boreholes were drilled within or close to the area of the "Harklowa peninsula" (Fig. 10). Lithological description of these cores is enclosed in Table 1. In pnost cases the rocks drilled in the peninsula area represent breccias or conglomerates of highly disorganized structures (Figs. 11 13) Generally, the breccias consist of angular to subangutar, tan domly oriented rock fragments (clasts), mostly mudstones/shales and sandstones. Mudstone clasts usually have better roundness than the sandstone ones, and if only they are present breccia passes into conglomerate. Both rock types are

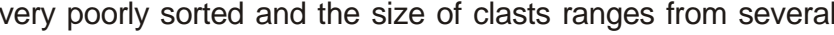
millimetres to four centimetres. Clasts display various shapes and those of sandstones are very often almost isomeric (Fig. 13B). In a few cores, mudstone and sandstone clasts reveal ductile deformation, they are strongly elongated and distorted, and their margins/borders are blurred. In such cases, the differentiation between clasts and matrix is to some extent arbitrary, espers of mudstone tend to pass gradually into matrix (Fig. 12A). Plastic deformation and strong elongation of some clasts emphasise fluidal structure of some breccias. Clasts are scattered in structureless matrix without any preferred orientation. Matrix-supported breccias prevail, although clast-supported ones also occur or sometimes in a single core change from one type into another is visible. The matrix consists of muddy material, light or dark grey and green-grey in colour, less often red and olive-green colours are dominant.

Based on the nature of the matrix and clasts, the breccias can be classified into two types (groups):

- breccia in which clasts are diversified in shape, size, roundness and especially in lithology, which is different from the lithology of the matrix (Figs. 11A, B, 12A and 13A, B). This is the more common variant of the breccias, occurring in boreholes 

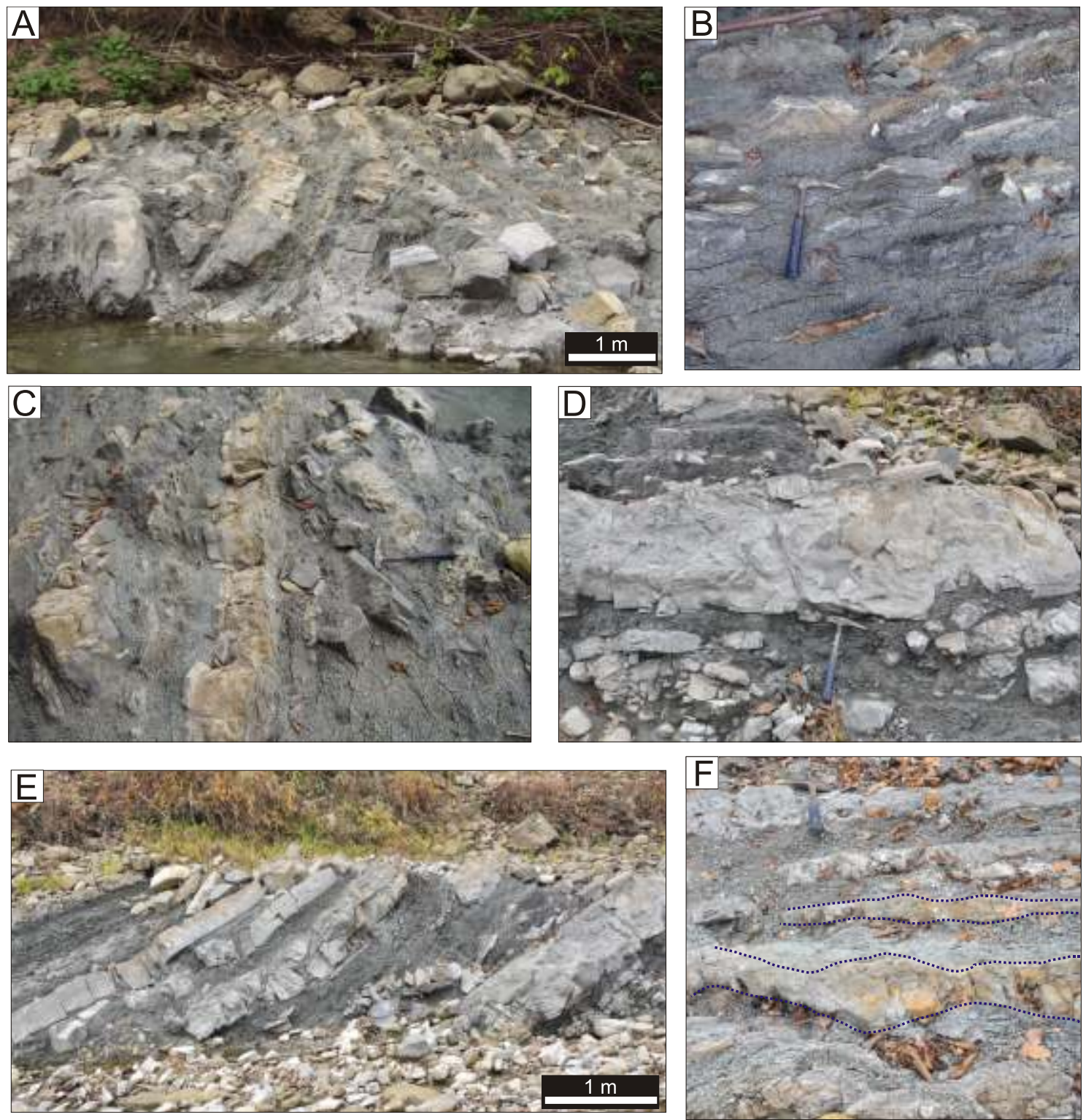

Fig. 8. Examples of mélange and broken formation within Ropianka Formation (Sękówka Stream)

A - angular and elongated blocks of fractured sandstones embedded in shaly matrix; $\mathbf{B}, \mathbf{C}$ - details of A, some of the sandstone clasts are elongated parallel or subparallel to the scaly fabric of matrix forming a pseudo-bedding, others are rotated slightly oblique; $\mathbf{D}$-shale injections into sandstone blocks (on the left), contained in scaly matrix; $\mathbf{E}$-continuous sandstone layers, fractured and interbedded by intervals of matrix displaying scaly fabric that includes smaller sandstone clasts (BrFm2); $\mathbf{F}$ - pinch-and-swell structures within BrFm2

no. W3-W10, W17, W19 and W21. Clasts include various types of sandstones and mudstones that show significant differences in colour, which is mainly dark grey (almost black) to light grey, green-grey, olive-green and red, and both calcareous or non-calcareous varieties are present. This type of breccia corresponds to the defined herein mèlange $\mathrm{Me2}$.

- breccia in which clasts and matrix have similar lithological character, thus only native clasts are presen (Figs. 12B and 13D), cohsisting of fragments of grey, fine-gramed sametstones and caldareous light grey mudstones that are mixed in grey, clayey-silty matrix. Usually, the matrix is brighter than the clasts. This type of breccia was drilled in boreholes no. W1, W2, W18 and W20. It can be referred to the broken formation (BrFm1) from the upper Krosno succession occurring along the Siary Stream.
In a few boreholes (W11-W16), none of the brecciated rocks were drilled and only sandstones were encountered. They are usually represented by fine-grained sandstones, yellow-green, non-calcareous, rich in glauconite and muscovite, with subordinately occurring green-brown calcareous mudstone. These boreholes are concentrated in the middle, elevated part of the "Hfrkiowa peninsulp", and are surrounded by boreholes with brec\&ias (Fig. 10).

\section{MICROPALAEONTOLOGICAL ANALYSES}

Among the forty four samples studied, four were barren of any microfossils and one contained only pyritised diatoms. All foraminiferal taxa identified in other samples are listed in $\mathrm{Ap}-$ 

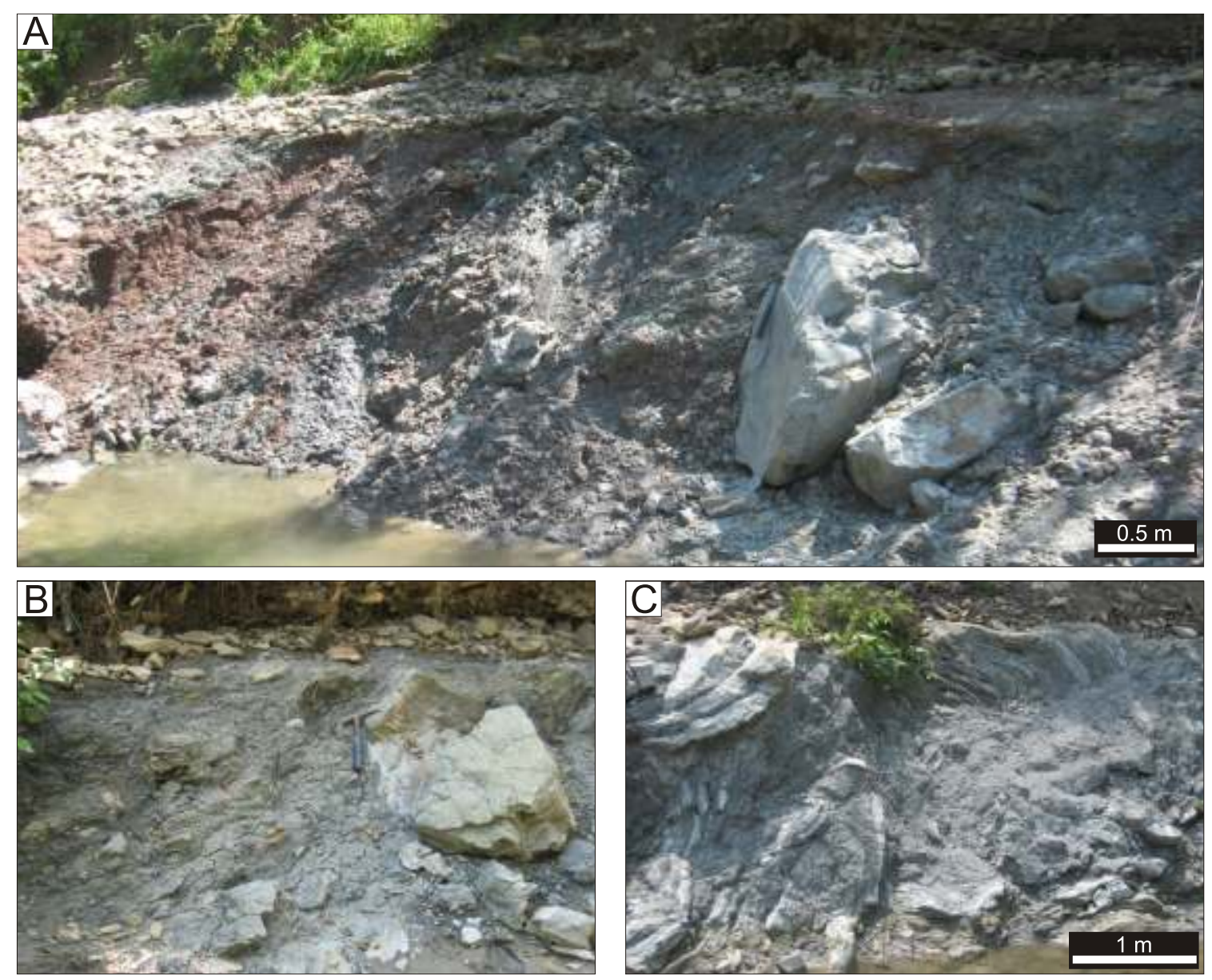

Fig. 9. Examples of mélange exposed along Libuszanka Stream

A - red and bluish-grey clayey matrix including blocks of Ropianka type sandstones; B - blocks of sandstone in matrix characterized by brecciated texture - matrix is made up of clays supporting millimetre scale clasts; C - folded and partly disrupted sandstone layers within clayey matrix

pendixes $1-3^{*}$. Entirely agglutinated assemblages were found in ten samples from chaotic deposits and in fifteen agglutinated forms are the dominant group in the assemblages, which are generally rich in foraminifera. Another nine samples from the chaotic deposits yielded much less abundant assemblages, but calcareous benthic or planktonic specimens are their main component. There are no marked differences in the foraminiferal content between cutting and core samples from similar deposits of individual boreholes.

In the chaotic deposits about 45 genera and 70 species of agglutinated foraminifera have been recorded. They represent the autochthonous fauna of mainly Maastrichtian-Paleocene or Paleocene and Middle Eocene redeposited flysch deposits. Benthic calcareous taxa belong to 29 genera with 24 identified species. Some of them represent most solution-resistant taxa of Eocene age. The others are common elements of the Oligocene assemblages, and very few are known from the Miocene. Planktonic foraminifera belong to five Cretaceous genera with three recognized species. The other identified 25 species are mainly Eocene and Oligocene forms, and a few are Miocene taxa. Photos of the most characteristic taxa are presented on Figures 14-16.

Foraminiferal assemblages and age control. The biostratigraphy of identified foraminiferal taxa are mainly based on their known occurrences in the Outer Carpathians described by Geroch and Nowak (1984), Odrzywolska-Bieńkowa and Olszewska (1996), Olszewska et al. (1996), and Olszewska (1997). Other papers such as Olszewska and Szymakowska (1984), Garecka and Olszewska (1998), Bąk (2005), Kaminski and Gradstein (2005), Pearson et al. (2006) and Peryt (2013) were also used in foraminiferal determinations and analyses. The samples referred below are described by the borehole number and depth of their recovery.

Microfaunal assemblage from a core sample W1 $(2.0 \mathrm{~m})$, consists of rare calcareous benthic and planktonic foraminifera, found in the smallest fraction $(<0.063 \mathrm{~mm}$; Appendix 1). The planktonic species Tenuitella munda indicates an Early Oligocene age.

The core sample W2 $(5.0 \mathrm{~m})$ consists of a poor and badly preserved mixed assemblage with tubular forms of agglutinated

* Supplementary data associated with this article can be found, in the online version, at doi: 10.7306/gq.1273 


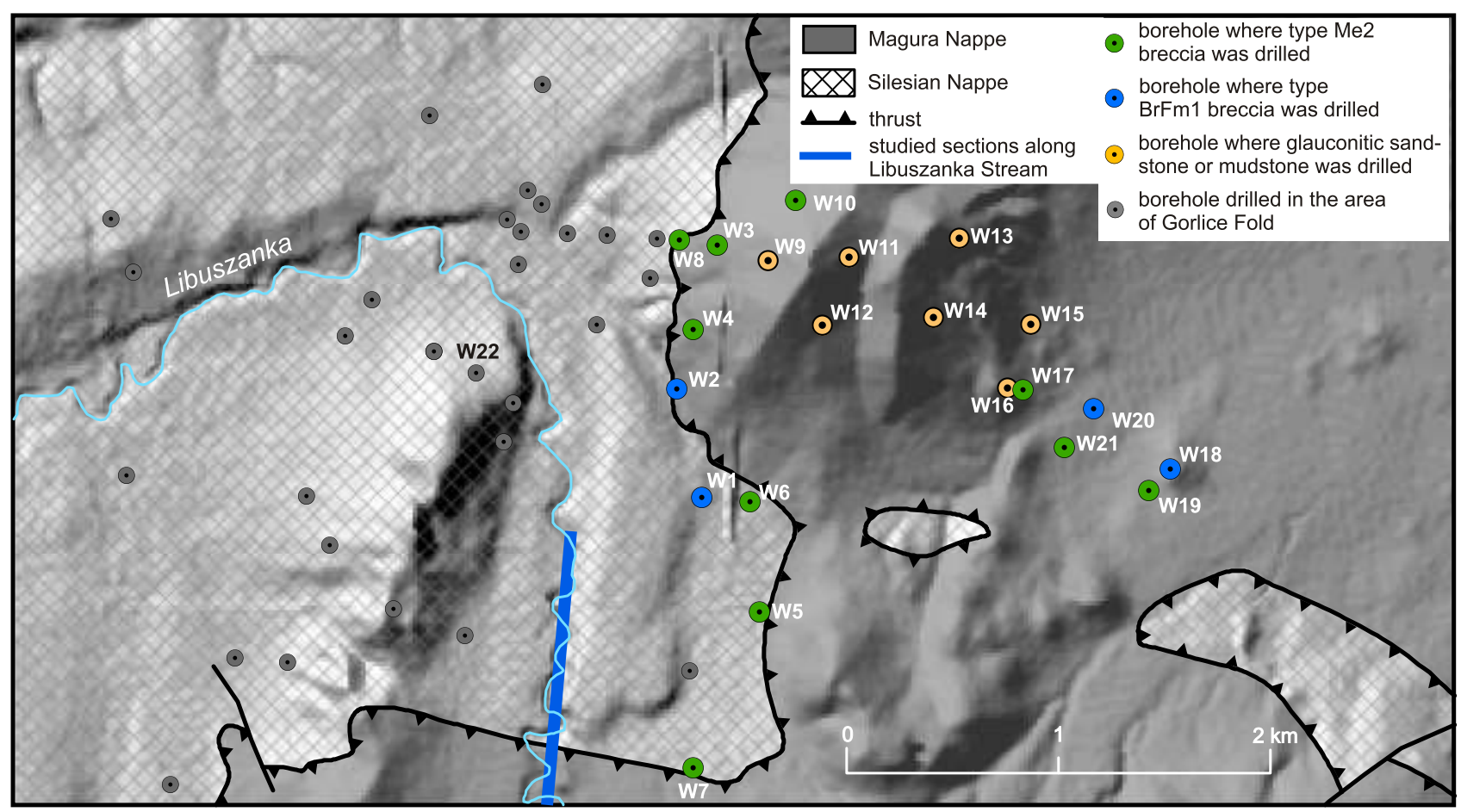

Fig. 10. Location of shallow boreholes

Shaded relief image as a background, geology according to the interpretation presented in the Figure $3 \mathrm{~A}$

foraminifera and rare calcareous benthic and planktonic foraminifera. Turborotalia ampliapertura points to an age within its stratigraphic range, which is the latest Eocene-Early Oligocene. The presence of Virgulinella chalkophila and Tenuitella munda documents an Early Oligocene age of the second core sample W2 (6.5 m).

Rich and well-preserved agglutinated foramini covered from two cutting samples of borehole W3 (Appendix 1) They represent typical deep-water agglutinated assemblage of the flysch type DWAF (deep-water agglutinated foraminifera; Kaminski and Gradstein, 2005) with Annectina grzybowskii, Rzehakina fissistomata and Spiroplectammina spectabilis indicating a Paleocene age. One core sample $(8.0 \mathrm{~m})$ contained a less numerous assemblage of a Maastrichtian/Paleocene age with Remesella varians, Dorothia crassa and poorly preserved calcareous benthic Nodosaria sp. and Eponides sp.

The cuttings sample W4 $(2.9 \mathrm{~m})$ contained a relatively abundant assemblage with dominant agglutinated taxa. Some sparse and poorly preserved planktonic forms were found as well (Appendix 1). Two stratigraphic groups of foraminifera can be distinguished. The Paleocene is based on the presence of Rzehakina fissistomata, and planktonic Subbotina cf. patagonica and S. velascoensis, and the Middle Eocene is indicated by Reticulophragmium amplectens and single specimen of planktonic Acarinina bullbrooki. The next cuttings sample $(5.0 \mathrm{~m})$ contained a less numerous and mixed assemblage with Saccamminoides carpathicus, the index species of the Early Eocene zone of agglutinated foraminifera. A few varied in colour specimens of benthic and planktonic forms were found as well. They probably represent a younger element, however, their precise taxonomic identification was not possible due to the very poor preservation.

The core sample W4 $(10.0 \mathrm{~m})$ yielded a rich and diversified assemblage. It consists of agglutinated, calcareous benthic and planktonic foraminifera, some fish teeth, diatoms and Echino- idea spines. With respect to the age a few groups of foraminifera can be distinguished. The agglutinated taxa with Reticulophragmium amplectens, single specimens of Acarinina bulbrooki and Cibicidoides grimsdalei represent a Middle Eocene assemblage. Calcareous benthic Falsoplanulina ammophila, Asterigerina rotula, and Pararotalia lithothamnica are species known from shallow water settings and along with the planktonic species Subbotina corpulenta indicate Late Eocene. The planktonic species Paragloborotalia nana, Turborotalia ampliapertura, T. increbescens, Globigerina ouachitaensis appear in the Late Eocene and commonly occur in the Late Eocene/Early Oligocene assemblages of marly deposits, however, some of these species display longer stratigraphic ranges. Tenuitellinata ciperoensis, G. angulisuturalis, G. anguliofficinalis represent the Oligocene. Siphonina reticulata, Globigerina concinna, Globigerinoides cf. primordius, G. trilobus indicate Miocene (Early-?Middle) (Cicha et al., 1998).

A core sample recovered from W5 $(9.5 \mathrm{~m})$ contained an assemblage dominated by agglutinated taxa with a few specimens of calcareous benthic and planktonic foraminifera. The presence of Reticulophragmium amplectens and Saccamminoides carpathicus suggests that the agglutinated assemblage is not younger than Middle Eocene. A single specimen of planktonic species Globigerina praebulloides displays a different state of preservation and most probably is the youngest component of this microfauna. In the Outer Carpathians this species occurs from the Upper Eocene through the Lower Miocene.

Core sample W17 $(5.7 \mathrm{~m})$ yielded an almost entirely calcareous assemblage dominated by planktonic foraminifera with only a single specimen of an agglutinated form. The taxa display varied stratigraphic ranges and are similar in taxonomic composition to the sample from borehole W4 $(10.0 \mathrm{~m})$. Subbotina corpulenta is a common component of the Late Eocene assemblages; Turborotalia ampliapertura, Tenuitella liverovskae, Tenuitellinata angustiumbilicata, Subbotina cf. 
Lithology of rocks drilled in the area of the "Harklowa peninsula"

\begin{tabular}{|c|c|c|c|c|}
\hline $\begin{array}{l}\text { No. } \\
\text { borehole }\end{array}$ & $\begin{array}{l}\text { Depth } \\
{[\mathrm{m}]}\end{array}$ & $\begin{array}{l}\text { Coring } \\
\text { interval } \\
{[\mathrm{m}]}\end{array}$ & $\begin{array}{c}\text { Core } \\
\text { recovery } \\
{[\mathrm{m}]}\end{array}$ & Lithological description \\
\hline W1 & 4.3 & $1.8-4.3$ & 0.44 & $\begin{array}{l}\text { Breccia consisting of dark grey, angular clasts of shales in light grey, clayey matrix, strongly } \\
\text { calcareous }\end{array}$ \\
\hline W2 & 6.9 & $3.5-6.9$ & 1.15 & $\begin{array}{l}\text { Upper part of core }(32 \mathrm{~cm}) \text { : beige to grey, fine-grained sandstone displaying cross lamination } \\
\text { underlined by dark minerals, with muscovite, medium hard, calcareous } \\
\text { Lower part of core }(83 \mathrm{~cm}) \text { : matrix-supported breccia consisting of clasts of fine-grained } \\
\text { sandstones within dark green-grey to black silty matrix, calcareous }\end{array}$ \\
\hline W3 & 9.0 & $6.5-9.0$ & 0.70 & $\begin{array}{l}\text { Upper part of core }(25 \mathrm{~cm}) \text { : matrix-supported breccia consisting of clasts of yellow, fine-grained } \\
\text { sandstone, with calcite veins, calcareous, mixed in dark green-grey, clayey-silty calcareous matrix } \\
\text { Lower part of core }(45 \mathrm{~cm}) \text { : clast-supported breccia consisting of clasts of light grey sandstones, } \\
\text { calcareous, laminated, with lots of muscovite and non-calcareous red shales, mixed in dark grey, } \\
\text { clayey-silty calcareous matrix }\end{array}$ \\
\hline W4 & 10.0 & $7.5-10.0$ & 0.72 & $\begin{array}{l}\text { Matrix-supported breccia/conglomerate consisting of grey sandstone and dark green-grey mudstone } \\
\text { clasts, angular to subrounded, mixed in green-grey, clayey-silty matrix, slightly calcareous }\end{array}$ \\
\hline W5 & 9.6 & $9.0-9.6$ & 0.56 & $\begin{array}{l}\text { Matrix-supported breccia consisting of olive, red and russet muddy matrix, non-calcareous, } \\
\text { and clasts of light and dark grey fine-grained sandstones and dark grey shales }\end{array}$ \\
\hline W6 & 9.45 & $6.0-9.45$ & 2.13 & $\begin{array}{l}\text { Matrix-supported breccia including angular clasts of green-grey fine-grained sandstones, } \\
\text { laminated, slightly calcareous and dark green-grey shales, mixed in olive-green, red and russet } \\
\text { clayey matrix, non-calcareous }\end{array}$ \\
\hline W7 & 10.0 & $7.5-10.0$ & 2.1 & $\begin{array}{l}\text { Matrix-supported breccia including angular clasts of grey-green fine-grained sandstones, } \\
\text { laminated, non-calcareous and olive-green shales, mixed in olive-green, red and russet } \\
\text { clayey matrix, non-calcareous }\end{array}$ \\
\hline W8 & 9.5 & $5.3-9.5$ & 0.5 & $\begin{array}{l}\text { Matrix-supported breccia/conglomerate, very brittle, consisting of millimetre to } 1 \mathrm{~cm} \text { clasts of dark } \\
\text { grey to black sandy mudstone, with lots of detritus and muscovite, matrix is light grey in colour, } \\
\text { with lots of muscovite }\end{array}$ \\
\hline W9 & 2.8 & $0.9-2.8$ & cuttings & $\begin{array}{l}\text { Clasts of fine-grained sandstones, yellow-grey, hard, with glauconite, non-calcareous, } \\
\text { clasts up to } 30 \mathrm{~cm}\end{array}$ \\
\hline W10 & 8.5 & $6.0-8.5$ & 0.7 & $\begin{array}{l}\text { Matrix-supported breccia consisting of angular to subrounded clasts of grey, very fine-grained } \\
\text { sandstones and dark grey mudstones, up to } 3 \mathrm{~cm} \text {, both types are non-calcareous, some of them } \\
\text { display ductile deformation, they are mixed in olive-green and dark grey, clayey-silty matrix, } \\
\text { non-calcareous }\end{array}$ \\
\hline W11 & 7.6 & $4.3-7.6$ & 0.1 & $\begin{array}{l}\text { Medium-grained sandstone, blue-grey, rusty and red on weathered surface, with glauconite, } \\
\text { cut by several calcite veins, very hard, calcareous }\end{array}$ \\
\hline W12 & 8.0 & $5.3-8.0$ & 0.7 & $\begin{array}{l}\text { Upper part of core }(26 \mathrm{~cm}) \text { : fine-grained sandstone, light grey, rusty yellow and red on weathered } \\
\text { surface, cross laminated, with muscovite and glauconite, very hard, cut by several calcite veins, } \\
\text { calcareous } \\
\text { Lower part of core }(39 \mathrm{~cm}) \text { : light grey, marly mudstone, rusty on weathered surface, very hard }\end{array}$ \\
\hline W13 & 5.6 & $2.8-5.6$ & 1.5 & Green-brown mudstone, very hard, with muscovite, dark brown on weathered surface, calcareous \\
\hline W14 & 6.2 & $3.0-6.2$ & 1.6 & $\begin{array}{l}\text { Upper part of core }(81 \mathrm{~cm}) \text { : fine-grained sandstone, yellow-green, laminated (convolute } \\
\text { lamination?), very hard, with lots of glauconite and muscovite, non-calcareous } \\
\text { Middle part of core }(44 \mathrm{~cm}) \text { : medium grained sandstone, yellow-green, cross laminated, water } \\
\text { escape structures, very hard, with a lot of glauconite, non-calcareous } \\
\text { Lower part of core }(39 \mathrm{~cm}) \text { : coarse grained sandstone (at the upper part of the core) } \\
\text { and medium grained (at the bottom), yellow-green, rusty yellow on weathered surface, very hard, } \\
\text { with a lot of glauconite and muscovite, non-calcareous }\end{array}$ \\
\hline W15 & 4.1 & $2.2-4.1$ & 1.2 & $\begin{array}{l}\text { Grey mudstone, green-brown on weathered surface, very hard, massive, with muscovite, } \\
\text { non-calcareous }\end{array}$ \\
\hline W16 & 3.8 & $2.0-2.8$ & 0.2 & $\begin{array}{l}\text { Fine-grained sandstone, light grey, rusty yellow and red on weathered surface, parallel } \\
\text { and convolute laminated with dark laminae, very hard, with muscovite, glauconite, cut by calcite } \\
\text { veins, calcareous } \\
\text { Rusty-green mudstone, brittle, } \mathrm{HCl}^{-}\end{array}$ \\
\hline W17 & 5.7 & $4.5-5.7$ & 0.9 & $\begin{array}{l}\text { Matrix-supported and partly clast-supported breccia, clasts are up to } 3 \mathrm{~cm} \text {, angular to subangular } \\
\text { and consist of light to dark grey mudstones and very fine-grained, laminated sandstones, } \\
\text { calcareous, matrix is light to dark grey, calcareous }\end{array}$ \\
\hline W18 & 6.0 & $3.7-6.0$ & 1.06 & $\begin{array}{l}\text { Upper part of core }(26 \mathrm{~cm}) \text { : very fine-grained sandstone, grey-blue in colour, light yellow-brown } \\
\text { when weathered, calcareous, very hard, fractured, with calcite veins } \\
\text { Middle part of core }(32 \mathrm{~cm}) \text { : clast-supported breccia consisting of angular rock fragments of grey } \\
\text { fine-grained sandstones and calcareous light grey shales, mixed in grey, clayey-silty matrix } \\
\text { Lower part of core }(48 \mathrm{~cm}) \text { : grey-green mudstone, with silty irregular laminae, very hard, calcareous }\end{array}$ \\
\hline W19 & 13.4 & $10.5-13.4$ & 2.00 & $\begin{array}{l}\text { Matrix-supported breccia consisting of clasts of varicoloured mudstones (red, olive-green, light } \\
\text { grey), non-calcareous and light grey, fine-grained sandstones, hard, slightly calcareous } \\
\text { or non-calcareous, which are mixed in a dark, clayey-silty matrix }\end{array}$ \\
\hline W20 & 7.0 & $4.3-7.0$ & 1.44 & $\begin{array}{l}\text { Matrix-supported breccia consisting of angular to subangular clasts of light and dark grey } \\
\text { calcareous mudstones and fine-grained calcareous sandstone, parallel laminated, with } \\
\text { deformational structures, which are mixed in light grey, muddy calcareous matrix }\end{array}$ \\
\hline W21 & 10.2 & $7.4-10.2$ & 2.20 & $\begin{array}{l}\text { Matrix-supported breccia consisting of angular clasts of varicoloured mudstones (red, olive-green, } \\
\text { light grey), non-calcareous and light grey, fine-grained sandstones, hard, slightly calcareous or } \\
\text { non-calcareous, which are mixed in a dark, clayey-silty matrix }\end{array}$ \\
\hline
\end{tabular}



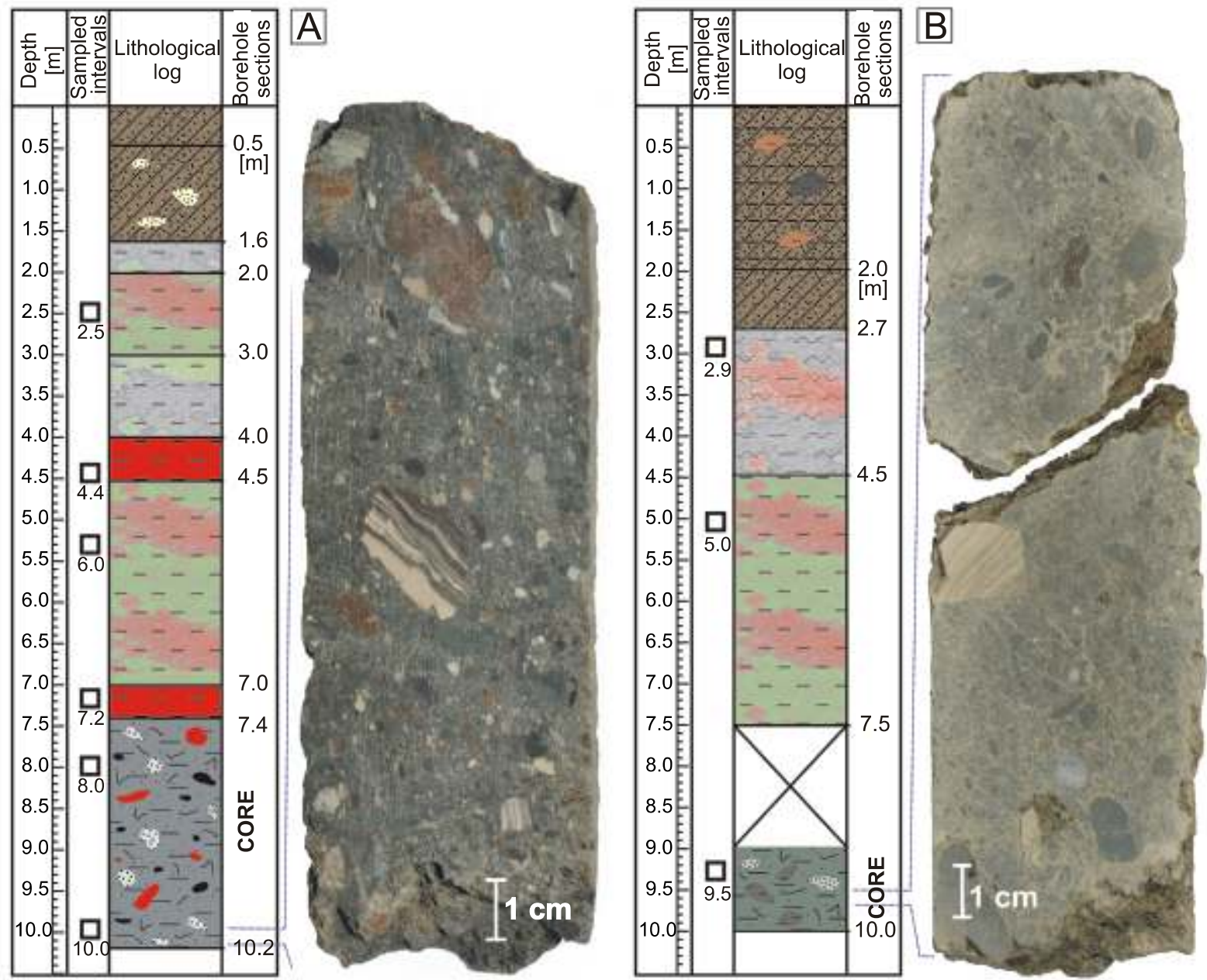

Fig. 11. Examples of lithological logs and core photos of investigatory boreholes (W21 - left and W4 - right)

A - borehole in which eluvial deposits consist of red, olive-green and blue-grey clays with shale fragments, cored interval includes variety of shale and sandstone clasts within dark grey matrix; B - borehole with similar to A eluvial part but slightly different cored rock (lack of red shale clasts, lighter, green-grey matrix); for explanations see Figure 12; colours in the logs correspond to the colour of eluvium/cored rock

angiporoides, Globigerina officinalis, G. ouachitensis in the Polish Outer Carpathians are found in Late Eocene-Early Oligocene assemblages. Tenuitellinata ciperoensis and Virgulinella chalkophila are the Oligocene species; Globigerina concinna, Globigerinoides quadrilobatus, Globoturborotalia cf. woodi and the benthic form Siphonina reticulata indicate Miocene (Early-?Middle).

Microfossils recovered from borehole W18 are very sparse. Calcareous foraminifera display a poor state of preservation and planktonic forms are small in size. The cutting sample consists of a few agglutinated foraminifere (Appendix 2) and some single specimens of calcareous benthic and planktonic foraminifera. Agglutinated taxa, the calcareous benthic Oridorsalis umbonatus and planktonic Globigerinatheka sp. are reworked from the marly Eocene deposits. A single specimen of a juvenile calcareous benthic determined as Anomalinoides sp. (Fig. $15 \mathrm{E})$ as well as planktonic Tenuitellinata angustiumbilicata, Tenuitella sp. cf. pseudoedita most probably represent a younger element, at least Oligocene. Two core samples (Appendix 2) yielded poor assemblages with rare specimens of calcareous benthic taxa and single specimens of the planktonic genus Tenuitefta. Foramninifiera from boretrote W20 display a simnitar character but they are even more impoverished. In core sample
(4.5 m) Tenuitella munda and Paragloborotalia nana were present among other rare specimens of planktonic foraminifera. The character of assemblages from the W18 and W20 boreholes, described above, and their taxonomic composition suggest at least an Oligocene age.

The foraminiferal assemblages recovered from two horeholes W19 and W21 display a similar character (Appendix 2). The foraminifera are abundant and represent nixed assemblages with respect to the taxonomic composition, age and colour of the shells. The agglutinated taxa considerably outnumber the calcareous benthic and planktonic forms. The state of preservation of the latter group is poor. Most of the calcareous specimens are either corroded or diagenetically altered. The group of agglutinated foraminifera, commonly recorded from the Paleocene or Maastrichtian/Paleocene flysch deposits, with characteristic species Annectina grzybowskii, Rzehakina fissistomata and Spiroplectammina spectabilis dominates the assemblages. The second numerous group with Reticulophragmium amplectens, represents Middle Eocene. Apart from the agglutinated components, in the cuttings sample at 5.5-6.0 m from borehole W19 the following planktonic foraminifera were also found: Late Campanian-Maastrichtian Globotruncanella havanensis, Paleocene and Paleocene/Early Eocene species 

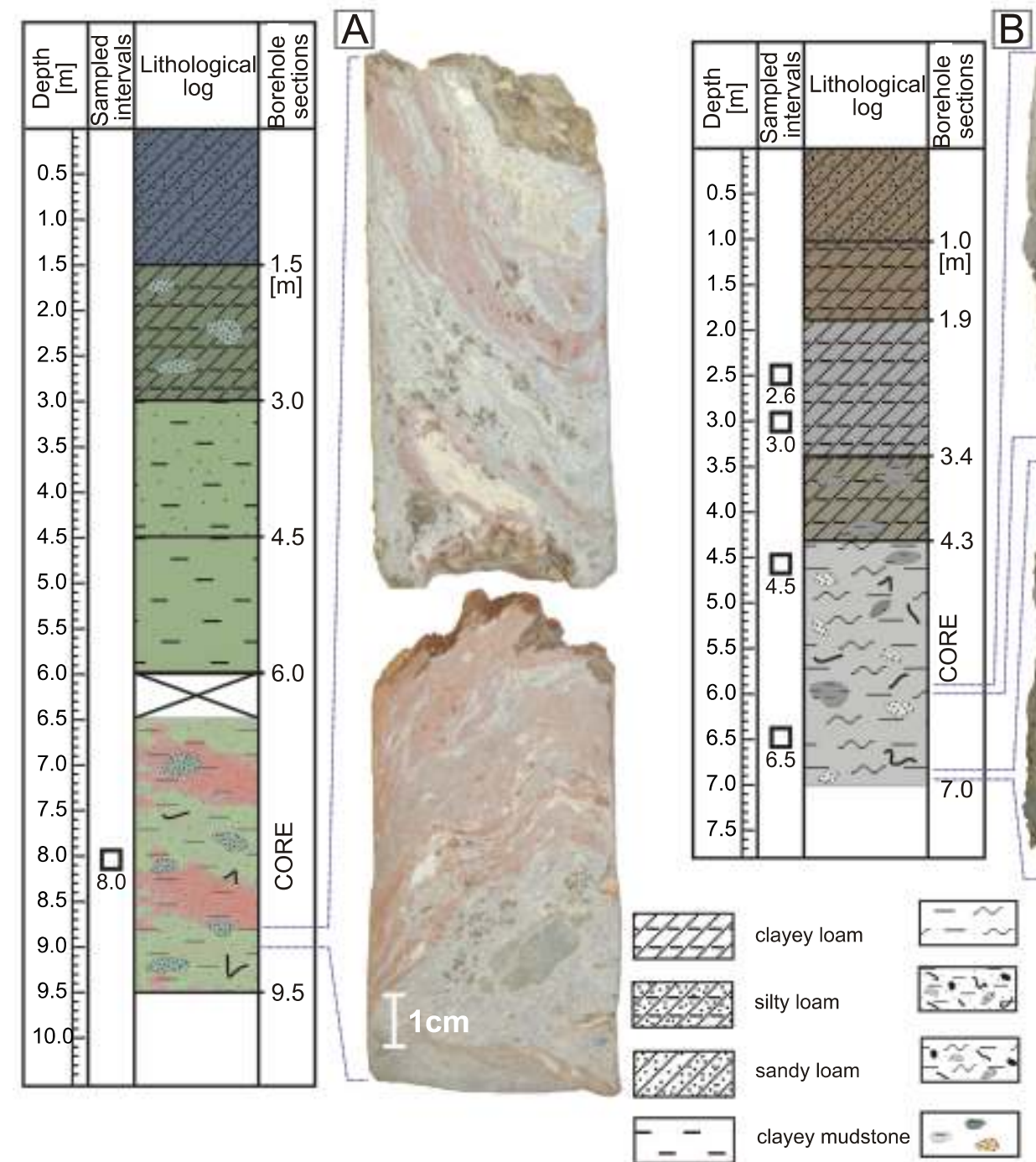

B
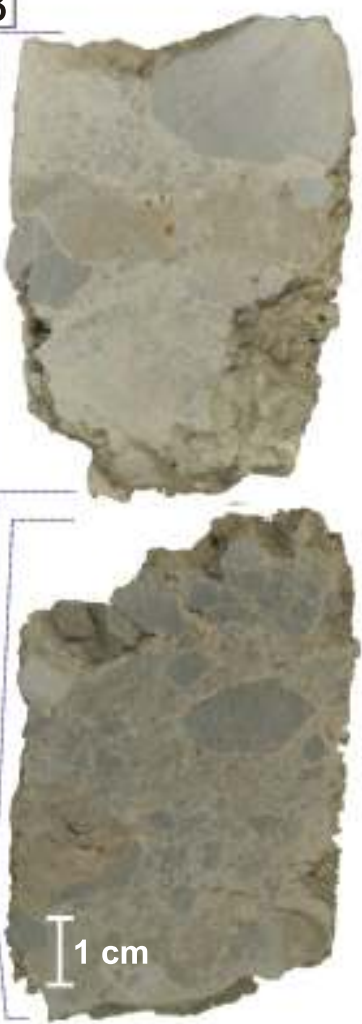

marly mudstone

disorganized gravelly mudstone, clayey/silty

disorganized gravelly mudstone, marly

sandstone and shale clasts

Fig. 12. Examples of lithological logs and core photos of investigatory boreholes (W7 - left and W20 - right)

A - borehole in which green shales prevail in eluvium, whereas cored interval includes ductilely deformed clasts and matrix, subordinately angular sandstone clasts; $\mathbf{B}$ - borehole characterized by the same lithological type matrix and clasts, the latter consist of grey calcareous shales and sandstones, matrix is slightly lighter but also grey and calcareous

Subbotina triloculinoides and Morozovella cf. marginodentata, and commonly occurring in the Middle Eocene Acarinina bulbrooki and Subbotina hagni. Calcareous benthic foraminifera are very rare and not significant due to their poor preservation. In the samples from borehole W19 very small and single specimens of another calcareous form have been also noticed, however, their taxonomic identification is uncertain. These are Cibicides cf. lopjanicus, Tenuitella cf. denseconnexa (sample 5.5-6.0 m), Cibicides sp. (aff. borislavensis) (sample 10.9 m) and Caucasina cf. coprolithoides (sample $12.4 \mathrm{~m}$ ). Their stratigraphic occurrences may indicate at least Oligocene. In the core sample recovered from $8.0 \mathrm{~m}$ depth in borehole W21 a single specimen of the Late Albian/Cenomanian genus Rotalipora was found along with Globotruncanita stuartiformis, known from the Late Santonian through Maastrichtian (Premoli-Silva and Sliter, 2002). Their co-occurrence in the same sample indicates probably double reworking of the oldest form (see Bąk and Oszczypko, 2000).
Two samples collected from the chaotic deposits exposed in the Libuszanka Streanr section consiiकt of entirely agglutinated foraminifera (Appendix 3). Some elements of the Paleocene DWAF assernblage were found in sample S1 while the sample $\mathrm{S} 2$ yielded less numerous and rather long ranging taxa commonly occurring in the Late Cretace us through Eocene. Another three samples from the Siary Stream section were barren of foraminifera.

In order to compare the data of chaoti and coherent rocks, samples from bore hole W22, which penet ated the undisturbed Hieroglyphic Beds of the Silesian Nappe (Fig. 10), are presented herein. All the samples yielded rich entirely agglutinated foraminiferal assermblages (Appendix 3). The majority of taxa are common but rather long ranging elements of the Paleocene-Eocene deep-water agglutinated fo aminifera. The characteristic feature o is the abundant presence of Haplophragmoides walteri, Spiroplectammina spectabilis and Karrerulina coniformis along with, rarely reported from 

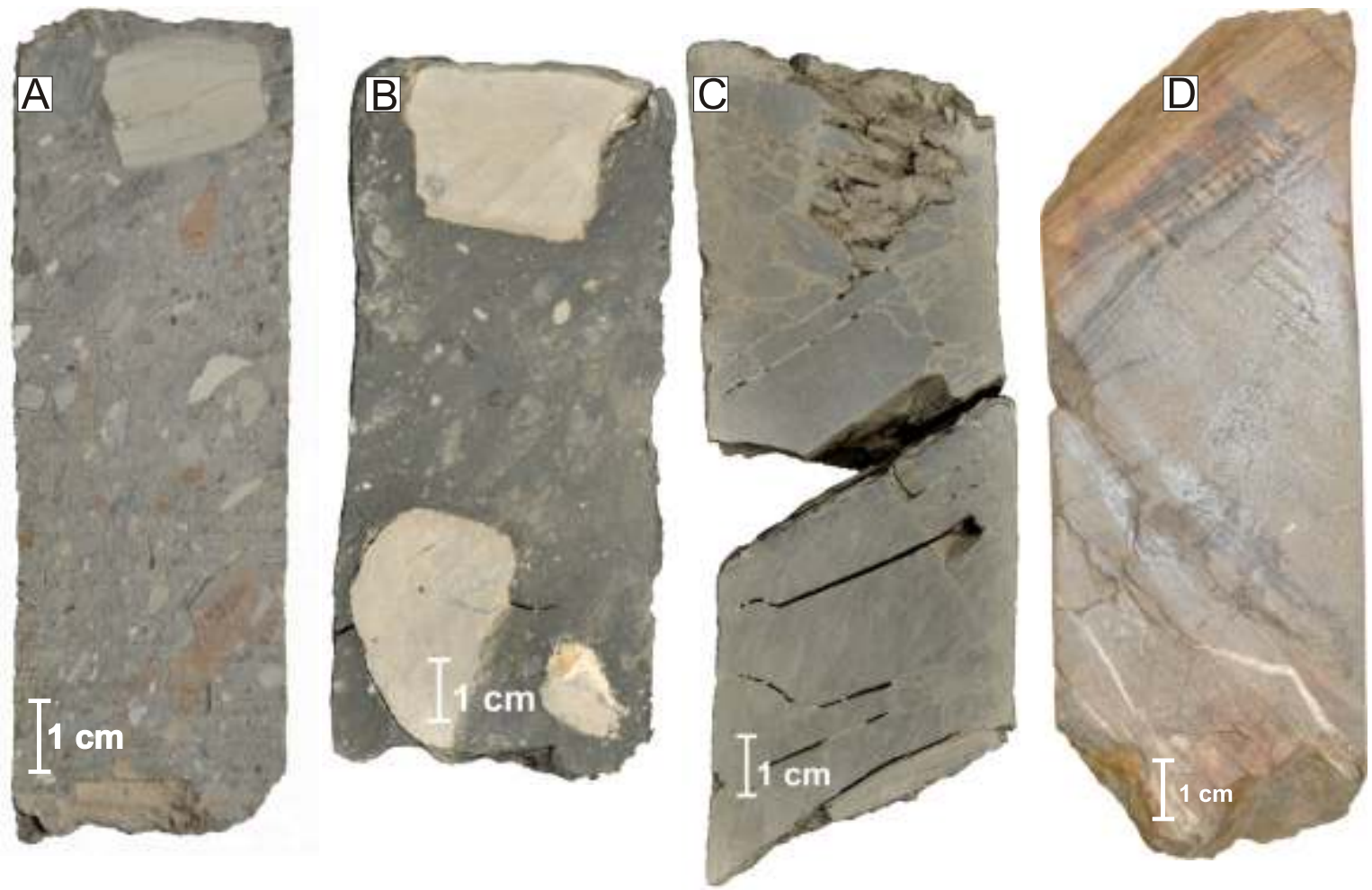

Fig. 13. Examples of rocks cored within the "Harklowa peninsula"

A - most common type of breccia - varicoloured shales and various sandstone clasts embedded in grey matrix; $\mathbf{B}$ - light grey, calcareous sandstone clasts within dark grey matrix; $\mathbf{C}$ - breccia built of the Krosno type sediments: grey, fine-grained sandstones and calcareous light grey mudstones mixed in grey, clayey-silty matrix; D - example of a glauconitic sandstone drilled in the central part of the peninsula

the Outer Carpathian flysch deposits, Psamminopelta gradsteini, Eratidus gerochi and Popovia beckmanni. The stratigraphic ranges of these latter species indicate a Middle Eocene age (Kaminski and Gradstein, 2005).

\section{DISCUSSION AND SUMMARY}

Our field observations and the results of micropalaeontological and lithological analyses of cores indicate the occurrence of deposits consisting of an argillaceous matrix with poorly sorted, angular to sub-angular blocks of shales and sandstones in the Gorlice region, representing mélanges or broken formations. The lithological logs of boreholes and the cored rocks within the "Harklowa peninsula" clearly show the mixed character of the deposits building the peninsula, which is also reflected by the character of the microfossils. These deposits include material derived from different lithostratigraphic units and different facies zones.

The micropalaeontological analyses revealed that the rocks forming the chaotic deposits represent the latest Cretaceous to Early Miocene time interval. The character and taxonomical composition of the latest Cretaceous-Paleocene mainly agglutinated assemblages are typical of the Ropianka Formation. The Early-Middle Eocene agglutinated foraminifera are common in the Łabowa Shale Formation. Both of these assemblages represent a characteristic flysch-type, deep-water fauna pointing to the deposition at considerable depth below the local CCD. The Middle-Late Eocene and latest Eocene/Early Oligocene calcareous benthic and planktonic foraminifera might have derived from marly, pelagic sediments that accumulated on the slopes above the local CCD. However, Late Eocene calcareous foraminiferal taxa are also present in smaller amounts in the flysch deposits of the Magura Nappe such as the SubMagura Beds (Malata, 2002). The Oligocene foraminifera, though considerably impoverished, consist of taxa commonly occurring in the Menilite-Krosno succession of the middle group of units in the Outer Carpathians (Olszewska, 1982; Garecka and Olszewska, 1998). The identified Miocene taxa, apart from Globigerinoides quadrilobatus, are also known from the upper part of the Krosno Beds as well as from the Gorlice Beds (Olszewska in: Jankowski, 2000).

Based on the results of the micropalaeontological analyses, age determination and the character of clasts (see Table 1) the potential lithostratigraphic units of the source material as well as the type of chaotic rock body, recognized in the core material are indicated in Table 2. There is a good correlation between the type of chaotic deposits and the microfaunal content resulting from the character of deposits included.

The broken formation (i.e. type BrFm1), drilled in the western and central part of the peninsula (Fig. 10) and exposed in the Siary Stream section, is exclusively composed of Krosno type material from the upper part of the Silesian succession. BrFm2 includes rocks belonging only to the Ropianka Formation of the Magura succession. Such rocks are also the main component of the Me1, which subordinately contains the variegated shales of the Łabowa Formation and possibly some sandstone fragments from the Krosno Beds. Mélange of the Me2-type, found within the "Harklowa peninsula", both in the field (Libuszanka Stream) and in the boreholes, displays the most complex composition. Rock fragments and argillaceous material of the Ropianka and Łabowa formations constitute its 


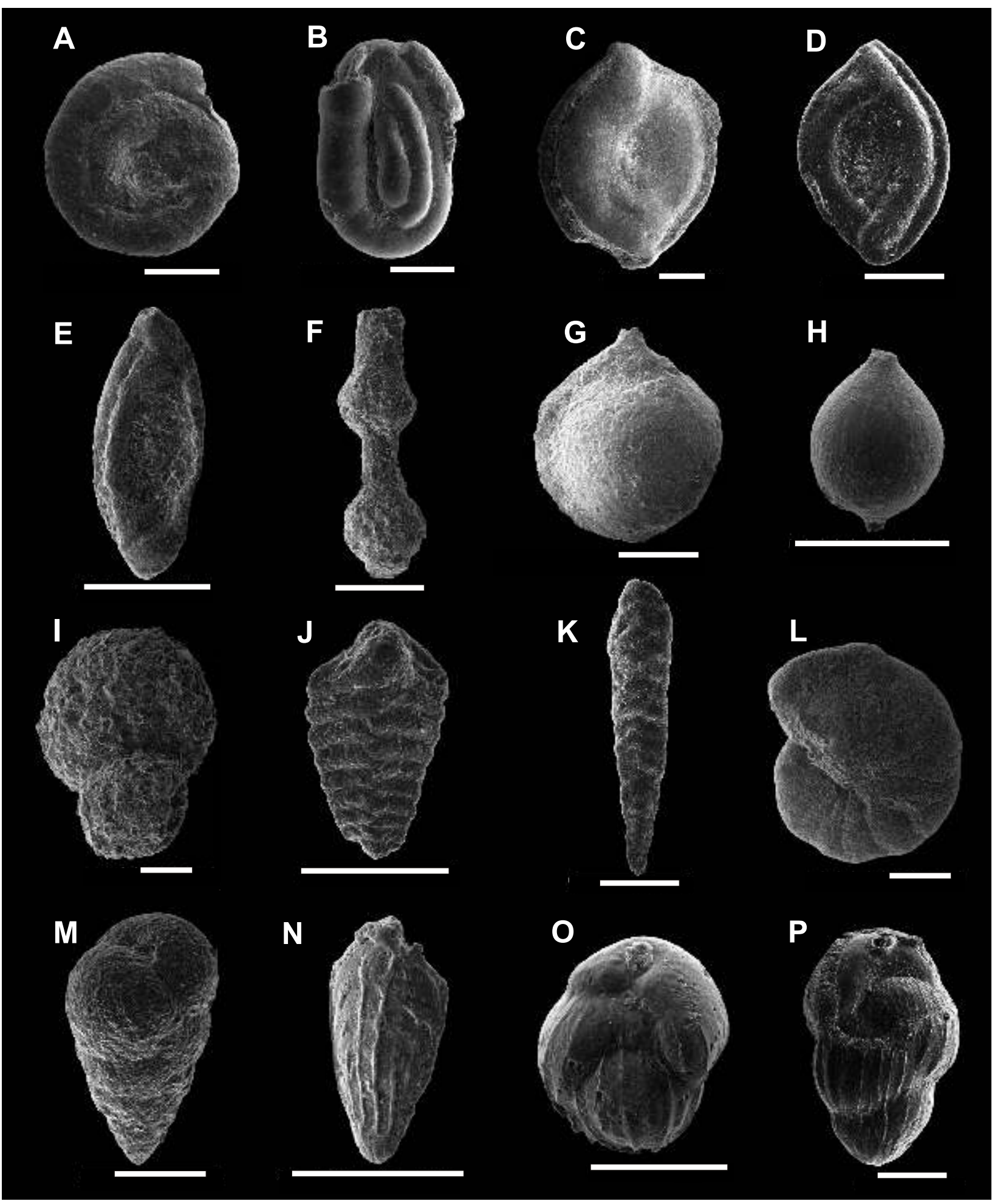

Fig. 14. SEM images of selected benthic foraminifera from chaotic deposits of the Gorlice area (scale bars $200 \mu \mathrm{m}$ )

A - Ammodiscus latus Grzybowski, sample W19, 12.4 m; B - Annectina grzybowskii (Jurkiewicz), sample W21, 8.0 m; C Rzehakina epigona (Rzehak), sample W21, 8.0 m; D - Rzehakina fissistomata (Grzybowski), sample W3, 6.0 m; E - Rzehakina minima Cushman and Renz, sample W21, 8.0 m; F-Caudammina excelsa (Dylą anka), sample W21, 7.2 m; G - Caudammina gigantea (Geroch), sample W19, 5.5-6.0 m; H - Caudammina ovula (Grzybowski), sample W21, 8.0 m; I - Reophax pilulifer Brady, sample W19, $12.4 \mathrm{~m} ; \mathbf{J}$ - Spiroplectammina dentata (Alth), sample W3, $0.5 \mathrm{~m} ; \mathbf{K}$ - Spiroplectammina spectabilis (Grzybowski), sample W3, $0.5 \mathrm{~m}$; L - Reticulophragmium amplectens (Grzybowski), sample W19, $12.4 \mathrm{~m} ; \mathbf{M}$ - Remesella varians (Glaessner), sample W3, $8.0 \mathrm{~m} ; \mathbf{N}$ - Bolivina cf. scalprata Schwager, sample W18, $5.5 \mathrm{~m}$; O - Hofkeruva sp., sample W4, $10.0 \mathrm{~m}$; P - Uvigerina longistriata Perconig, sample W4, $10.0 \mathrm{~m}$ 


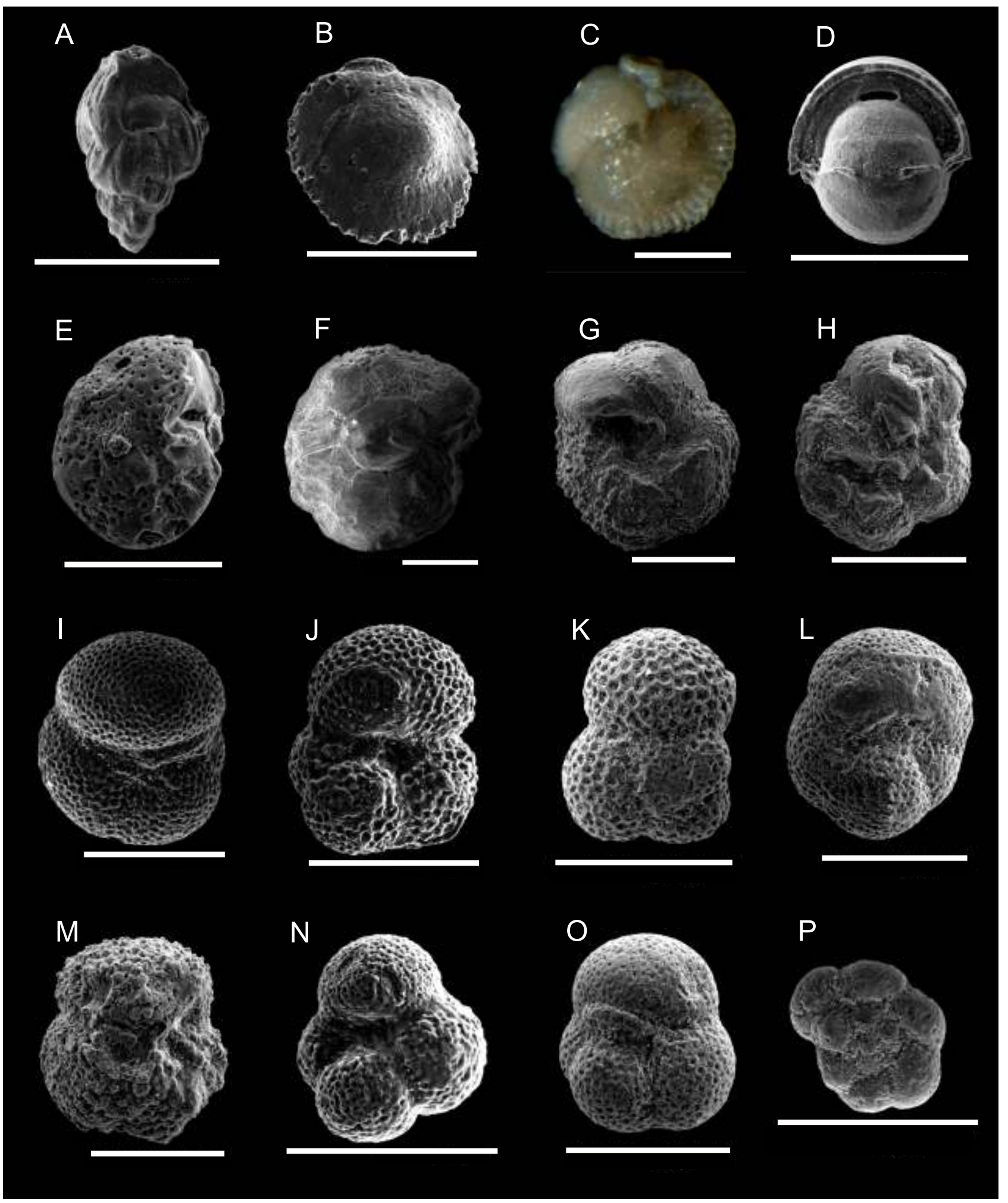

Fig. 15. SEM images and light photomicrographs of selected benthic and planktonic foraminifera from chaotic deposits of the Gorlice area (scale bars $200 \mu \mathrm{m}$ )

A - Angulogerina cf. angulosa (Williamson), sample W18, 4.15-4.5 m; B, C - Siphonina reticulata (Czjzek), sample W4, 10.0 m; D Pullenia bulloides (d'Orbigny), sample W4, $10.0 \mathrm{~m}$; E - Anomalinoides sp., sample W19, $12.4 \mathrm{~m}$; F - Pararotalia lithothamnica (Uhlig), sample W4, 10.0 m; G - Globotruncanita stuartiformis (Dalbiez), sample W21, 8.0 m; H - Rotalipora sp., sample W21, 8.0 m; I Subbotina velascoensis (Cushman), sample W4, $2.9 \mathrm{~m}$; J - Subbotina cf. patagonica (Todd and Kniker), sample W4, $2.9 \mathrm{~m} ; \mathbf{K}-$ Subbotina cf. patagonica (Todd and Kniker), sample W17, $5.7 \mathrm{~m}$; L - Turborotalia ampliapertura (Bolli), sample W17, $5.7 \mathrm{~m}$; M Acarinina bullbrooki (Bolli), sample W4, $10.0 \mathrm{~m}$; N - Subbotina corpulenta (Subbotina), sample W4, $10.0 \mathrm{~m}$; O - Subbotina cf. angiporoides (Hornibrook), sample W17, $5.7 \mathrm{~m}$; P - Tenuitella liverovskae (Bykova), sample W17, $5.7 \mathrm{~m}$ 


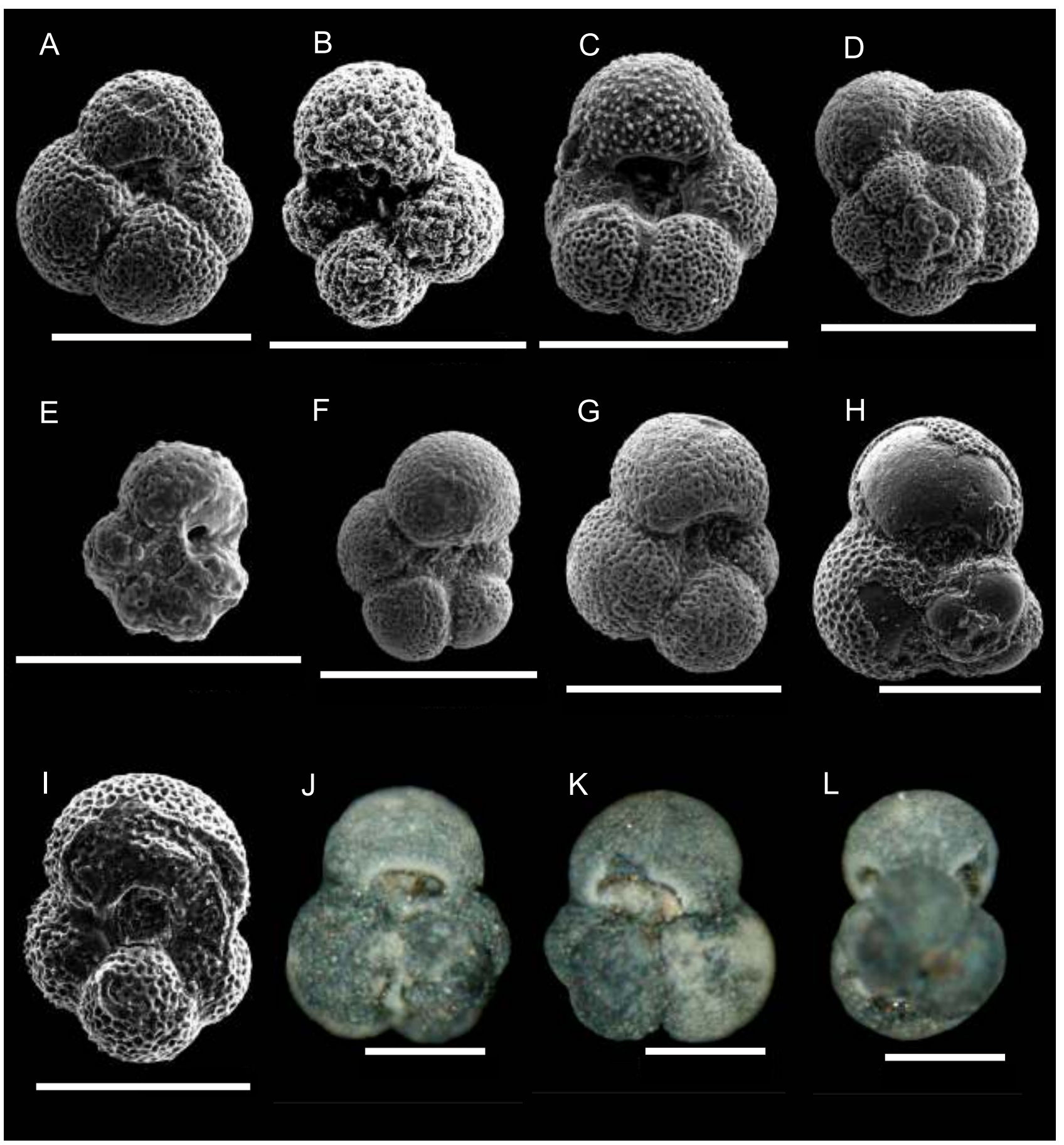

Fig. 16. SEM images and light photomicrographs of selected planktonic foraminifera from chaotic deposits of the Gorlice area (scale bars $200 \mu \mathrm{m}$ )

A - Globigerina ouachitaensis Howe and Wallace, sample W4, 10.0 m; B - Globigerina praebulloides Blow, sample W5, 9.5 m; C Tenuitellinata ciperoensis (Bolli), sample W4, $10.0 \mathrm{~m}$; D - Tenuitellinata ciperoensis (Bolli), sample W17, $5.7 \mathrm{~m}$; E - Tenuitella sp., sample W20, 4.5 m; F - Tenuitellinata sp., sample W17, 5.7 m; G - Globigerina bulloides d'Orbigny, sample W17, 5.7 m; H - Globigerinoides cf. primordius Blow and Banner, sample W4, $10.0 \mathrm{~m}$; I- Globoturborotalia cf. woodi (Jenkins), sample W4, $10.0 \mathrm{~m}$; J-L - Globigerinoides quadrilobatus (d'Orbigny), sample W17, $5.7 \mathrm{~m}$

main components. Facially, these components correspond to the marginal part of the Magura Unit. The other material that can be attributed to the Magura succession, is represented by clasts of glauconitic sandstones. Most probably they are derived from the Watkowa Sandstones of the Magura Beds. Within such material some elements of the Silesian succession and/or Fore-Magura facies zone are also incorporated. The lat- ter case seems to be more probable as several workers emphasised the similarity of the rocks building both, the "Harklowa peninsula" and outliers situated north of it, to those of the Fore-Magura group (Szymakowska, 1966, 1976; Koszarski and Koszarski, 1985; Jankowski, 2007). These elements are represented by the Oligocene sandstones and shales of the Krosno type. There are also Eocene deposits that resemble the Hiero- 
glyphic Beds, but their origin is unclear. An assumption of the Fore-Magura origin of this material is supported by the occurrence of marly matrix and calcareous foraminifera in some of the borehole samples. As mentioned before, such material could have been deposited and originally formed in shallower zones, such as that of the supposed ForeMagura sedimentation zone (Cieszkowski, 2002). The presence of a dark grey to black matrix (Fig. 13B) may also be an indirect indicator of the ForeMagura provenance of the mélange deposits.

The results of drillings presented herein contribute new information about the geological character of the "Harklowa peninsula", whose deposits are exposed only in fragments, therefore various interpretations have been proposed. Block in matrix structure and considerable mixing of the drilled deposits, in terms of both their lithology and age, support the opinion that the peninsula is built of chaotic rock body (Jankowski, 1997a, 2007).

According to Jankowski (2007), chaotic rocks of various origins (tectonic and sedimentary) are quite common in the Gorlice region. They are presented on the maps as one, nondifferentiated unit of the Gorlice Beds (Kopciowski et al., 1997a, b; Jankowski et al., 2004). Our studies allowed us to distinguish four types of chaotic deposits according to the lithology of their components and deformation style. As a result it enables the recognition of the processes that led to stratal disruption and emplacement of the deposits:

- BrFm1 exposed in the Siary Stream section is, in our opinion, an effect of submarine slumping/sliding of poorly-lithified sediments, thus it can be regarded as an olistostrome. Such origin is indicated by the internal structure of the BrFm1 body, i.e. the occurrence of slump folds and their alignment parallel to the bedding surface, completely random orientation of smaller blocks and lack of scaly fabric in the matrix, together with conformable contacts of the body with the underlying coherent strata and interbedding with packets of turbidite layers (e.g., Hsü, 1968; Jacobi, 1984; Lash, 1987; Festa et al., 2010a; Ogata et al., 2012).

- Me1 and BrFm2 form a genetically related continuum of disrupted rocks. The intensity of deformation diminishes gradually from the north to the south, starting from typical block-in-matrix deposits through units with original bedding partly preserved to coherent sedimentary layers. The origin of $\mathrm{Me} 1$ and BrFm2 as a result of tectonic deformation is manifested by their structure, especially a structurally ordered block-in-matrix fabric, which is thought to be a defining characteristic of tectonic mélanges (e.g., Onishi and Kimura, 1995; Osozawa et al., 2009). Moreover, boudinaged sandstones or pinch-and-swell structures, occurring mainly within BrFm2, and strong alignment of the elongated clasts of Me1 parallel to the regional thrust, can be regarded as the diagnostic features of tectonic strain (e.g., Bettelli and Vannucch, 2003; Codegone et al., 2012a; Festa et al., 2012, 2013).

- Structurally the Me2 is very similar to BrFm1, exhibiting a blocks in matrix fabric with very diversified block sizes, slump folds, and a brecciated texture of the matrix, therefore we interpret it as a result of gravitational displacement of sediments. As suggested by Jankowski (2007), slumping or debris flow mechanisms are proposed to explain the origin of Me2.

Formation of all defined herein types of mélange and broken formation could have been connected with the development of an accretionary wedge within the Magura area. Their emplacement is related to different structural positions within the wedge. Festa et al. (2010a, b) proposed a classification of mélanges and presented models of their tectonic setting. In our simplified

model, which refers to one of the models included in the abovementioned papers, the tectonic position of defined types of chaotic rocks is depicted (Fig. 17).

In BrFm1 the composition of blocks is monomictic, suggesting only local and intra-formational downslope remobilization of sediments. The BrFm1 was formed at the southern slopes of the Silesian Basin, before the accretionary wedge entered the basin. An occurrence of several layers or lenses of BrFm1 within the uppermost part of the Krosno Beds may be a response to the respective phases of wedge evolution within the Magura area. Large earthquakes and/or initial faulting of the southern slopes of the Silesian Basin, related to the advancing accretionary wedge, seems to be the most probable triggering mechanisms causing slope instability and mass transport movements (Festa et al., 2010a). BrFm1 represents the olistostrome, which directly predates the time when the accretionary wedge reached the margins of the Silesian Basin. Codegone et al. (2012b) described a similar type of broken formation in the fine-grained turbidite succession from the Central Appalachians that was induced by early tectonic pulses related to the advancing accretionary wedge. Although, the age is not supported by microfossil analyses as three samples from BrFm1 (Fig. 4) did not yield any data, on the basis of ages obtained from Me2 deposits and other data (e.g., Oszczypko, 2006), it can be concluded that BrFm1 was formed during the Late Oligocene near the Oligocene/Miocene boundary.

Me2 in the "Harklowa peninsula" area also represents an olistostrome but its composition and the age of matrix suggest that it was formed after the Magura Nappe reached the southern parts of the Silesian Basin. According to obtained micropalaeontological data this could have happened at the Aquitanian/Burdigalian boundary, which is consistent with the data presented by Oszczypko (2006). Me2 represents a mass-wasting body, emplaced at the front of an advancing accretionary wedge, therefore it is composed mainly of material belonging to different formations of the Magura Nappe, which in the Early Miocene formed the northern margins of the wedge. Me2 corresponds to the precursory olistostrome in Festa et al. (2010a, b) classification, which in turn is a type of sub-nappe mélanges. Among factors controlling the formation of such types of mélanges, Festa et al. (2010a) singled out earthquakes on active margins, oversteeping slope angles, thrusting, and duplexing Jankowski (2007) proposed a hypothesis of slumping from an active slope or from an active fault scar in order to explain the emplacement of the "Harklowa peninsula" deposits. According to Festa et al. (2013) both the fault activity and the slope oversteeping related to migration of the wedge front, could represent potential triggering mechanisms for slope instability. These mechanisms are very likely to induce the sediment failure that formed Me2. 
Compilation of data and interpretation

\begin{tabular}{|c|c|c|c|c|}
\hline Borehole & $\begin{array}{l}\text { Depth } \\
\text { of core sample } \\
\text { (cutting sample) }\end{array}$ & Ages (based on foraminifera) & $\begin{array}{l}\text { Lithostratigraphic composition } \\
\text { of recovered deposits }\end{array}$ & $\begin{array}{l}\text { Type of chaotic } \\
\text { rock-body }\end{array}$ \\
\hline W1 & $2.0 \mathrm{~m}$ & at least Oligocene & Krosno Beds & BrFm1 \\
\hline \multirow{2}{*}{ W2 } & $5.0 \mathrm{~m}$ & latest Eocene-Early Oligocene & \multirow{4}{*}{ Ropianka Fm. + Łabowa Fm. } & \multirow{4}{*}{ BrFm1 } \\
\hline & $6.5 \mathrm{~m}$ & Early Oligocene & & \\
\hline \multirow{3}{*}{ W3 } & $0.5 \mathrm{~m}$ & Paleocene & & \\
\hline & $6.0 \mathrm{~m}$ & Paleocene & & \\
\hline & $8.0 \mathrm{~m}$ & Maastrichtian/Paleocene & Ropianka Fm. & \multirow{3}{*}{ Me2 } \\
\hline \multirow[b]{3}{*}{ W4 } & $2.9 \mathrm{~m}$ & Paleocene + Middle Eocene & Ropianka Fm. + Łabowa Fm. & \\
\hline & $5.0 \mathrm{~m}$ & Early Eocene + younger elements & Łabowa Fm. + ? & \\
\hline & $10.0 \mathrm{~m}$ & $\begin{array}{c}\text { Middle Eocene + Late Eocene/Early } \\
\text { Oligocene + Oligocene + Miocene } \\
\text { (Early-? Middle) }\end{array}$ & $\begin{array}{l}\text { Sub-Magura Beds* }+ \text { Krosno Beds } \\
+ \text { matrix of Me2 }\end{array}$ & Me2 \\
\hline W5 & $9.5 \mathrm{~m}$ & not younger than Middle Eocene & Łabowa Fm. & Me2 \\
\hline W6 & $8.0 \mathrm{~m}$ & latest Cretaceous/Paleocene & $\begin{array}{l}\text { Ropianka Fm. and variegated shales } \\
\text { within formation or Łabowa Fm. }\end{array}$ & Me2 \\
\hline W7 & $9.5 \mathrm{~m}$ & $\begin{array}{c}\text { latest Cretaceous/Paleocene } \\
\text { + Middle Eocene }\end{array}$ & Ropianka Fm. + Łabowa Fm. & Me2 \\
\hline W10 & $6.5 \mathrm{~m}$ & Early-?Middle Eocene & ?Hieroglyphic Beds & $\mathrm{Me} 2$ \\
\hline W17 & $5.7 \mathrm{~m}$ & $\begin{array}{c}\text { Late Eocene + Late Eocene- } \\
\text { Early Oligocene + Oligocene + Miocene } \\
\text { (Early-?Middle) }\end{array}$ & $\begin{array}{l}\text { Sub-Magura Beds* }+ \text { Krosno Beds } \\
+ \text { matrix of Me2 }\end{array}$ & Me2 \\
\hline \multirow{3}{*}{ W18 } & $3.5 \mathrm{~m}$ & Eocene + at least Oligocene & \multirow{3}{*}{$\begin{array}{l}\text { Sub-Magura Beds* }+ \text { Krosno Beds } \\
\text { Krosno Beds }\end{array}$} & \multirow{3}{*}{$\begin{array}{l}\mathrm{Me2} \\
\mathrm{BrFm} 1 \\
\mathrm{BrFm} 1\end{array}$} \\
\hline & $4.15-4.5 \mathrm{~m}$ & at least Oligocene & & \\
\hline & $5.5 \mathrm{~m}$ & at least Oligocene & & \\
\hline \multirow{6}{*}{ W19 } & $3.0 \mathrm{~m}$ & $\begin{array}{l}\text { Late Cretaceous + Paleocene + } \\
\text { Middle Eocene }\end{array}$ & \multirow{6}{*}{$\begin{array}{c}\text { Ropianka Fm. + Łabowa Formation + } \\
\text { Krosno Beds }\end{array}$} & \\
\hline & $4.5 \mathrm{~m}$ & Late Cretaceous + Paleocene + Eocene & & \\
\hline & $5.5-6.0 \mathrm{~m}$ & $\begin{array}{c}\text { Late Campanian-Maastrichtian + } \\
\text { Paleocene/Early Eocene + Middle Eocene } \\
\text { + at least Oligocene }\end{array}$ & & \\
\hline & $9.0 \mathrm{~m}$ & Paleocene + Early/Middle Eocene & & \\
\hline & $10.9 \mathrm{~m}$ & $\begin{array}{l}\text { Paleocene + Middle Eocene } \\
+ \text { at least Oligocene }\end{array}$ & & $\mathrm{Me} 2$ \\
\hline & $12.4 \mathrm{~m}$ & $\begin{array}{c}\text { Paleocene + Middle/Late Eocene } \\
+ \text { at least Oligocene }\end{array}$ & & Me2 \\
\hline \multirow{4}{*}{ W20 } & $2.6 \mathrm{~m}$ & at least Oligocene & \multirow{4}{*}{ Krosno Beds } & \multirow{4}{*}{$\begin{array}{l}\mathrm{BrFm1} \\
\mathrm{BrFm1}\end{array}$} \\
\hline & $3.0 \mathrm{~m}$ & at least Oligocene & & \\
\hline & $4.5 \mathrm{~m}$ & at least Oligocene & & \\
\hline & $6.5 \mathrm{~m}$ & at least Oligocene & & \\
\hline \multirow{6}{*}{ W21 } & $2.5 \mathrm{~m}$ & Paleocene + Middle Eocene & \multirow{6}{*}{ Ropianka Fm. + Łabowa Fm. } & \multirow{6}{*}{$\begin{array}{l}\text { Me2 } \\
\text { Me2 }\end{array}$} \\
\hline & $4.4 \mathrm{~m}$ & ?Maastrichtian/Paleocene & & \\
\hline & $6.0 \mathrm{~m}$ & Paleocene + Early Eocene & & \\
\hline & $7.2 \mathrm{~m}$ & Paleocene + Middle Eocene & & \\
\hline & $8.0 \mathrm{~m}$ & $\begin{array}{c}\text { Albian/Cenomanian + Later } \\
\text { Santonian-Maastrichtian + Paleocene } \\
\text { + Middle Eocene }\end{array}$ & & \\
\hline & $10.0 \mathrm{~m}$ & Paleocene + Middle Eocene & & \\
\hline \multirow{5}{*}{ W22 } & $2.5 \mathrm{~m}$ & Middle Eocene & \multirow{5}{*}{$\begin{array}{l}\text { Hieroglyphic Beds (undisturbed } \\
\text { deposits of the Silesian Nappe) }\end{array}$} & \\
\hline & $4.0 \mathrm{~m}$ & Middle Eocene & & \\
\hline & $5.5 \mathrm{~m}$ & Middle Eocene & & \\
\hline & $8.0 \mathrm{~m}$ & Middle Eocene & & \\
\hline & $9.0 \mathrm{~m}$ & Middle Eocene & & \\
\hline S1 & outcrop sample & Paleocene & Ropianka Fm. & Me2 \\
\hline S2 & outcrop sample & Late Cretaceous-Eocene & Ropianka Fm. + Łabowa Fm. & $\mathrm{Me} 2$ \\
\hline
\end{tabular}

*Sub-Magura Beds - deposits of the Siary Subunit which occur between the Łabowa Shale Fm. and Watkowa Sandstone member of the Magura Fm. 
The deposits within the peninsula are mostly the result of collapse of the Magura wedge front and emplacement of exotic material into the Silesian Basin, but they also include intrabasinal Silesian sediments that are indicated by the occurrence of Krosno-type chaotic rocks (BrFm1, Fig. 10). The association of exotic and intrabasinal blocks in a precursory olistostrome is described by Lucente and Pini $(2003,2008)$ and Codegone et al. (2012a). Although, it cannot be excluded that the two boreholes with the Krosno type breccia, situated west of the peninsula (Fig. 10), may represent rather a tectonic breccia than a part of the peninsula mélange. This breccia would have been connected with a fault system confining the peninsula to the west that was inferred from our mapping work. A similar fault is also depicted in the maps of Jankowski et al. (2004) and Jankowski (2007). Small breccias at fault zones within the Krosno Beds can also be observed in the outcrops along Libuszanka Stream. Sandstones, drilled in the central part of the peninsula, may in turn represent the slipped blocks or single block of Magura provenance (the Watkowa type sandstones), thus they form a huge olistolith embedded in the brecciated matrix of Me2. Formation of the Me2 took place in the Early Miocene as indicated by our micropalaeontological data and the ones presented in the literature (Olszewska and Szymakowska, 1984; Jankowski, 2000).

The structural features characterizing Me1 and BrFm2 and their actual emplacement allows us to classify them as tectonic ones formed at the base of the Magura thrust. Thus, they correspond to tectonic mélanges at the base of a nappe in the subdivision of Festa et al. (2010a, b). Thrusting was the main mechanism inducing the stratal disruption. Me1 and BrFm2 were produced through layer-parallel extension/contraction at the wedge front of the accretionary complex (cf. Codegone et al., 2012a).

\section{CONCLUSIONS}

We presented new data obtained from geological mapping, drilling of shallow boreholes and detailed micropalaeontological analyses that enabled better understanding of geological history of the bordering zone between the Magura and Silesian nappes, east from Gorlice in the Polish Carpathians. The geology of this zone, including the so-called "Harklowa peninsula", was variously interpreted, i.e. as a part of the Magura Nappe, or as remnants of separate Jasło Nappe, or as a chaotic rock body of sedimentary and/or tectonic origin. Our data support the last interpretation, i.e. occurrence of disrupted body of rocks at the front of the Magura Nappe.

Detailed studies revealed presence of different types of mélange and broken formation in the area in question. Recognition of their geological character, the processes involved in their origin and spatial-temporal relationships between them, allowed for interpretation of the last evolutionary stages of both the Magura accretionary complex and the Silesian Basin:
- small-scale broken formation (BrFm1), that forms thick intervals within the uppermost part of turbidite Krosno succession, may be indirectly related to advancing accretionary wedge from the south. BrFm1 was probably formed in response to tectonic movements within the Magura area and predated the time Magura wedge reached the southern margins of the Silesian Basin. This broken formation is thought to developed at the Late Oligocene, although no micropalaeontological data were obtained;

- mélange building the "Harklowa peninsula" (defined herein as Me2) is in turn directly related to development of the accretionary wedge. It records the time when folded and uplifted deposits of the Magura succession formed the southern, active slope of the Silesian Basin. Along the slope slumping occurred and as a result sediments of chaotic structure were deposited within the basin, covering the Krosno Beds. This mélange represents the final stage of the Silesian Basin evolution that according to micropalaeontological data dates back to the Early Miocene;

- continuum of the Inoceramian type rocks starting from bedded succession through a gradual transition to broken formation (BrFm2), and finally to strongly deformed block-in-matrix arrangement (Me1) represents a tectonic disrupted body that was formed at the base of the Magura Nappe.

As regards the aspect of our study, it revealed that in a poorly outcropped area covered by vegetation, like the studied one, shallow exploration boreholes and micropalaeontological analyses can be a powerful tool in mélanges and broken formation recognition and interpretation of their origin. The boreholes drilled within the "Harklowa peninsula" showed first of all that it consists of mélange, secondly an internal structure of the mélange, i.e. occurrence of sandstone olistolith embedded in block-in-matrix material. Micropalaeontological study besides age data, can provide with important information helpful in differentiation between mélange and broken formation, especially when in mélange exotic blocks lithologically resemble its matrix.

Acknowledgements. This paper has been prepared on the basis of data gathered during geological mapping carried out for RWE Dea. We are grateful for the permission to publish the results, and special thanks go to J. Kotkiewicz, M. Dimke and K. Müller for stimulating discussions both in the field and office. We owe a debt of gratitude to J. Purchla for the favourable conditions in the Geokrak Company supporting our work on this paper. We thank our colleagues from Geokrak Company, especially W. Szeliga, J. Hejnar, P. Czwarkiel and D. Gmur for discussions and technical support in the various stages of the project. The manuscript was critically reviewed by $L$. Jankowski, M. Kaminski and an anonymous reviewer whose comments are much appreciated by the authors. We would like to thank T.M. Peryt for editorial suggestions and M. Kaminski for language corrections, which both significantly improved our manuscript.

\section{REFERENCES}

Bailey, E.B., McCallien, W.J., 1950. The Ankara mélange and the Anatolian thrust. Nature, 166: 938-943.

Bailey, E.B., McCallien, W.J., 1953. Serpentinite lavas, the Ankara mélange and the Anatolian thrust. Philosophical Transaction of the Royal Society of Edinburgh, 62: 403-442.
Barber, T., Brown, K., 1988. Mud diapirism: the origin of mélanges in accretionary complexes? Geology Today, 4: 89-94.

Bą, K., 2005. Foraminiferal biostratigraphy of the Egerian flysch sediments in the Silesian Nappe, Outer Carpathians, Polish part of the Bieszczady Mountains. Annales Societatis Geologorum Poloniae, 75: 71-93. 
Bąk, K., Oszczypko, N., 2000. Late Albian and Cenomanian redeposited foraminifera from Late Cretaceous-Paleocene deposits of the Rača Subunit (Magura Nappe, Polish Western Carpathians) and their paleogeographical significance. Geologica Carpathica, 51: 371-382.

Behr, H.J., Engel, W., Franke, W., 1982. Varisican wildflysch and nappe tectonics in the Saxothuringian zone (northeast Bavaria, west Germany). American Journal of Science, 282: 1438-1470.

Berkland, J.O., Raymond, L.A., Kramer, J.C., Moores, E.M., O'Day, M., 1972. What is Franciscan? AAPG Bulletin, 56: 2295-2302.

Bettelli, G., Vannucchi, P., 2003. Structural style of the offscraped Ligurian oceanic sequences of the Northern Apennines: new hypothesis concerning the development of mélange block-in-matrix fabric. Journal of Structural Geology, 25: 371-388.

Bird, J.M., 1969. Middle Ordovician gravity sliding - Taconic region. AAPG Memoir, 12: 670-686.

Bosellini, A., 1998. Scalloped versus faulted carbonate margins and the origin of basinal megabreccias. Memorie della Società Geologica Italiana, 53: 63-74

Cicha, I., Rögl, F., Rupp, C., Čtyroká, J., eds., 1998. Oligocene-Miocene Foraminifera of the Central Paratethys. Kramer, Frankfurt am Main.

Cieszkowski, M., 2002. Fore-Magura zone in the Polish sector of the Outer Carpathians. Geologica Carpathica - Special Issue, 53.

Cieszkowski, M., Polak, A., 1998. Oligocene Flysch deposits with associated olistostroms in the inner zone of the Silesian Nappe (North Outer Carpathians, Poland). Abstracts, XVI Congress, Carpatho-Balkan Geological Association, Vienna, Aug 30th-Sept. 2nd, Vienna, 95.

Cieszkowski, M., Oszczypko, N., Zuchiewicz, W., 1987. Late Cretaceous submarine slump in the Inoceramian beds of the Magura Nappe at Szczawa, Polish West Carpathians. Annales Societatis Geologorum Poloniae, 57: 189-201.

Cieszkowski, M., Golonka, J., Krobicki, M., Ślączka, A. Waśkowska, A., Wendorff, M., 2009. Olistoliths within the Silesian Series and their connections with evolutionary stages of the Silesian Basin (in Polish with English summary). Geologia, 35: 13-21.

Cieszkowski, M., Golonka, J., Ślączka, A., Waśkowska, A., 2012 Role of the olistostromes and olistoliths in tectonostratigraphic evolution of the Silesian Basin in the Outer West Carpathians. Tectonophysics, 568-569: 248-265.

Ciurej, A. Haczewski, G., 2012. The Tylawa Limestones - a re gional marker horizon in the Lower Oligocene of the Paratethys: diagnostic characteristics from the type area. Geological Quarterly, 56 (4): 833-844.

Codegone, G., Festa, A., Dilek, Y., Pini, G.A., 2011. Different types of Taconic mélanges s.I. and broken formations in the Hamburg Klippe (Central Appalachians, Pennsylvania). Rendiconti online Società Geologica Italiana, 15: 40-42.

Codegone, G., Festa, A., Dilek, Y., Pini, G.A., 2012a. Small-scale polygenetic mélanges in the Ligurian accretionary complex, Northern Apennines, Italy, and the role of shale diapirism in superposed mélange evolution in orogenic belts. Tectonophysics, 568-569: 170-184.

Codegone, G., Festa, A., Dilek, Y., 2012b. Formation of Taconic mélanges and broken formations in the Hamburg Klippe, Central Appalachian Orogenic Belt, Eastern Pennsylvania. Tectonophysics, 568-569: 215-229.

Cowan, D.S., 1974. Deformation and metamorphism of the Franciscan Subduction Zone Complex northwest of Pacheco Pass, California. GSA Bulletin, 85: 1623-1634.

Cowan, D.S., 1985. Structural styles in Mesozoic and Cenozoic mélanges in the western Cordillera of North America. GSA Bulletin, 96: 451-462.

De Libero, C.M., 1998. Sedimentary versus tectonic deformation in the "Argille Scagliose" of Mt. Modino (Northern Apennines). Giornale di Geologia, 56: 143-166.

Dellisanti, F., Pini, G.A., Tateo, F., Baudin, F., 2008. The role of tectonic shear strain on the illitization mechanism of mixed-lay- ers illite-smectite. A case study from a fault zone in the Northern Apennines, Italy. International Journal of Earth Sciences, 97 601-616.

Di Stefano, P., Alessi, A., Gullo, M., 1996. Mesozoic and Paleogene megabreccias in Southern Sicily. New data on the Triassic paleomargin of the Siculo-Tunisian platform. Facies, 34: 101-122.

Festa, A., Pini, G.A., Dilek, Y., Codegone, G., 2010a. Mélanges and mélange-forming processes: a historical overview and new concepts. International Geology Review, 52: 1040-1105.

Festa, A., Pini, G.A., Dilek, Y., Codegone, G., Vezzani, L., Ghisetti, F., Lucente, C.C., Ogata, K., 2010b. Peri-Adriatic mélanges and their evolution in the Tethyan realm. International Geology Review, 52: 369-406.

Festa, A., Dilek, Y., Pini, G.A., Codegone, G., Ogata, K., 2012. Mechanisms and processes of stratal disruption and mixing in the development of mélanges and broken formations: redefining and classifying mélanges. Tectonophysics, 568-569: 7-24.

Festa, A., Dilek, Y., Codegone, G., Cavagna, S., Pini, G.A., 2013 Structural anatomy of the Ligurian accretionary wedge (Monferrato, NW Italy), and evolution of superposed mélanges. GSA Bulletin, 125: 1580-1598.

Gansser, A., 1974. The ophiolite mélange: a world-wide problem on Tethyan examples. Eclogae Geologicae Helvetiae, 67: 479-507.

Garecka, M., Olszewska, B., 1998. Biostratigraphy of the Early Miocene of the Southern Poland based on planktic foraminifera and calcareous nannoplankton. Przegląd Geologiczny, 46: 712-721.

Gedl, P., Leszczyński, S., 2005. Palynology of the EoceneOligocene transition in the marginal zone of the Magura Nappe at Folusz (Western Carpathians, Poland). Geologica Carpathica, 56: 155-167.

Geroch, S., Nowak, W., 1984. Proposal of zonation for the Late Tithonian-Late Eocene based upon arenaceous Foraminifera from the Outer Carpathians, Poland. 2nd International Symposium on Benthic Foraminifera, Benthos 83, Pau 1983: 225-239.

Haczewski, G., 1989. Coccolith limestone horizons in the MeniliteKrosno Series (Oligocene, Carpathians): identification, correlation and origin (in Polish with English summary). Annales Societatis Geologorum Poloniae, 59: 435-523.

Hsü, K.J., 1968. Principles of mélanges and their bearing on the Franciscan-Knoxville Paradox. GSA Bullettin, 79: 1063-1074.

Hsü, K.J., 1974. Melanges and their distinction from olistostromes. SEPM Special Publication, 19: 321-333.

Jacobi, R.D., 1984. Modern submarine sediment slides and their implications for mélange and the Dunnage Formation in north-central Newfoundland. GSA Special Paper, 198: 81-102.

Jankowski, L., 1997a. Gorlice Beds - the youngest deposits of the southern part of the Silesian Nappe (in Polish with English summary). Przegląd Geologiczny, 45: 305-308.

Jankowski, L., 1997b. Szczegółowa mapa geologiczna Polski w skali 1: 50 000, ark. Rzepiennik - 88591 (in Polish). NAG PGI-NRI, Warszawa.

Jankowski, L., 2000. Geologia przedpola jednostki magurskiej nowe dane (in Polish). Posiedzenia Naukowe Państwowego Instytutu Geologicznego, 56: 79-82.

Jankowski, L., 2007. Chaotic complexes in Gorlice region (Polish Outer Carpathians) (in Polish with English summary). Biuletyn Państwowego Instytutu Geologicznego, 426: 27-52.

Jankowski, L., Kopciowski, R., Ryłko, W., 2004. Geological Map of the Outer Carpathians: borderlands of Poland, Ukraine and Slovakia, 1:200 000. NAG, PGI-NRI, Warszawa.

Jasionowicz, J., Szymakowska, F., 1963. An attempt to explain the origin of Magura Nappe outliers from the vicinity of Jasło and of the Subsilesian Nappe from the vicinity of Wielopole Skrzyńskie (in Polish with English summary). Rocznik Polskiego Towarzystwa Geologicznego, 33: 363-385.

Jucha, S., 1969. Les schistes de Jasło, leur importance pour la stratigraphie et la sédimentologie de la série ménilitique et des couches de Krosno (Carpathes flyscheuses) (in Polish with French summary). Prace Geologiczne Polskiej Akademii Nauk, 52: $1-128$ 
Kaminski, M.A., Gradstein, F.M., 2005. Atlas of Paleogene cosmopolitan deep-water agglutinated Foraminifera. Grzybowski Foundation Special Publication, 10.

Konarski, E., 1980. Wgłebna budowa karpackiej budowy fliszowe w rejonie gorlicko-krośnieńskim (in Polish). Wyd. Geol., Warszawa.

Konarski, E., 1986. Prognostyka poszukiwawcza gorlickiego obszaru naftowego (in Polish). Przegląd Geologiczny, 34: 502-509.

Kopciowski, R., Garecka, M., 1996. Najmłodsze utwory strefy Siar - jednostki magurskiej (in Polish). Przegląd Geologiczny, 44: 486-489.

Kopciowski, R., Zimnal, J., Jankowski, L., 1997a. Szczegółowa mapa geologiczna Polski w skali 1:50 000, ark. Osiek - 88590 (in Polish). NAG, PGI-NRI, Warszawa.

Kopciowski, R., Zimnal, Z., Chrząstowski, J., Jankowski, L., Szymakowska, F., 1997b. Szczegółowa mapa geologiczna Polski w skali 1:50 000, ark. Gorlice - 88102 (in Polish). NAG, PGI-NRI, Warszawa.

Kopf, A., 2002. Significance of mud volcanism. Reviews of Geophysics, 40: 1-51.

Koszarski, A., 1999. The Jasło Nappe versus Gorlice beds. A controversy at the front of Magura Nappe in the Jasło - Gorlice region (Polish Middle Carpathians). Geologica Carpathica, 50, Special Issue: 153-154.

Koszarski, A., 2001. Budowa geologiczna płaszczowiny jasielskiej na SW od Jasła (in Polish). Upublished PhD thesis, Jagiellonian University, Kraków.

Koszarski, A., Koszarski, L., 1985. Marginal zone of the Magura Nappe and its relation to lower units. In: Geology of the Middle Carpathians and the Carpathian Foredeep (eds. L. Koszarski) Guide to Excursion, 3: 216-224

Koszarski, A., Tokarski, A., 1965-1967. Szczegółowa mapa geologiczna Polski w skali 1:50 000 (bez utworów czwartorzędowych), region Karpat i Przedgórza, ark. Osiek (in Polish). Wyd. Geol., Warszawa.

Koszarski, L., 1966-1967. Szczegółowa mapa geologiczna Polsk w skali 1:50 000 (bez utworów czwartorzędowych), region Karpat i Przedgórza, ark. Jasło (in Polish). Wyd. Geol., Warszawa.

Koszarski, L., ytko, K., 1961. Jasło shales within the Menilite Krosno Series in the Middle Carpathians (in Polish with English summary). Biuletyn Instytutu Geologicznego, 166: 87-232.

Koszarski, L., ytko, K., 1966-1967. Szczegółowa mapa geologiczna Polski w skali 1:50 000 (bez utworów czwartorzedowych), region Karpat i Przedgórza, ark. Rzepiennik (in Polish). Wyd. Geol., Warszawa.

Ksią kiewicz, M., 1958. Submarine slumping in the Carpathian Flysch. Rocznik Polskiego Towarzystwa Geologicznego, 28: 123-151.

Ksią kiewicz, M., ed., 1962. Atlas geologiczny Polski (in Polish). Zagadnienia stratygraficzno-facjalne. Instytut Geologiczny, Warszawa.

Ksią kiewicz, M., 1977. Hypothesis of plate tectonic and origin of the Carpathians (in Polish with English summary). Rocznik Polskiego Towarzystwa Geologicznego, 47: 329-353.

Lash, G.G., 1987. Diverse mélanges of an ancient subduction complex. Geology, 15: 652-655.

Lucente, C.C., Pini, G.A., 2003. Anatomy and emplacement mechanism of a large submarine slide within the Miocene foredeep in the northern Apennines, Italy: a field perspective. American Journal of Science, 303: 565-602.

Lucente, C.C., Pini, G.A., 2008. Basin-wide mass-wasting complexes as markers of the Oligo-Miocene foredeep - accretionary wedge evolution in the northern Apennines, Italy. Basin Research, 20: 49-71.

Malata, E., 1981. The stratigraphy of the Magura nappe in the western part of the Beskid Wysoki Mts., Poland, based on microfauna (in Polish with English summary). Biuletyn Instytutu Geologicznego, 331: 103-116.

Malata, E., 2002. Albian-Early Miocene foraminiferal assemblages of the Magura Nappe (Polish Outer Carpathians). Geologica Carpathica, 53, special issue: 77-79.
Needham, D. T., Mackenzie, J. S., 1988. Structural evolution of the Shimanto Belt accretionary complex in the area of the Gokase River, Kyushu, SW Japan. Journal of Geological Society London, 145: 85-94.

Nemčok, M., Pogácsás, G., Pospíšil, L., 2006a. Activity timing of the main tectonic systems in the Carpathian-Pannonian region in relation to the rollback destruction of the lithosphere. AAPG Memoir, 84: 743-766.

Nemčok, M., Pospíšil, L., Hrušecký, I., Zsíros, T., 2006b. Subduction in the remnant Carpathian Flysch Basin. AAPG Memoir, 84: 767-785.

Nescieruk, P., Paul, Z., Ryłko, W., Szymakowska, F., Wójcik, A., ytko, K., 1995-1996. Mapa geologiczna Polski, arkusz Jasło, skala 1:200 000 (in Polish). B - mapa bez utworów powierzchniowych. NAG, PGI-NRI, Warszawa.

Odrzywolska-Bieńkowa, E., Olszewska, D. 1996. Rząd Foraminiferida Eichwald (in Polish). In: Budowa geologiczna Polski (eds. L. Malinowska and M. Piwocki): 530-614. Atlas skamieniałości przewodnich i charakterystycznych, część 3a, Neogen. Państwowy Instytut Geologiczny, Warszawa.

Ogata, K., Mutti, E., Pini, G.A., Tinterri, R., 2012. Mass transport-related stratal disruption within sedimentary mélanges: examples from the northern Apennines (Italy) and south-central Pyrenees (Spain). Tectonophysics, 568-569: 185-199.

Ogniben, L., 1953. "Argille scagliose" e "argille brecciate" in Sicilia. Bollettino del Servizio Geologico Italiano, 75: 279-289.

Olszewska, B., 1982. Some remarks on biostratigraphy of the Menillite-Krosno Series in the Polish Outer Carpathians (in Polish with English summary). Kwartalnik Geologiczny, 26 (1): 137-145.

Olszewska, B., 1997. Foraminiferal biostratigraphy of the Polish Outer Carpathians: a record of basin geohistory. Annales Societatis Geologorum Poloniae, 67: 325-337.

Olszewska, B., Szymakowska, F., 1984. The olistostrome at Kołaczyce near Jasto (Central Carpathians) and the time of its formation in the light of new micropaleontological studies (in Polish with English summary). Biuletyn Instytutu Geologicznego, 346: 117-142.

Olszewska, D., Odrzywolska-Bieńkowa, E., Giel, M.D., Po aryska, K., Szczechura, J., 1996. Rząd Foraminiferida Eichwald (in Polish). In: Budowa geologiczna Polski (eds. L. Malinowska and M. Piwocki): 45-216. Atlas skamieniałości przewodnich i charakterystycznych, część 3a, Paleogen. Państwowy Instytut Geologiczny, Warszawa.

Onishi, T.C., Kimura, G., 1995. Change in fabric of mélange in the Shimanto Belt, Japan: change in relative convergence? Tectonics, 14: 1273-1289

Orange, D.L., 1990. Criteria helpful in recognizing shear-zone and diapiric mélanges: examples from the Hoh accretionary complex, Olympic Peninsula, Washington. GSA Bulletin, 102 935-951.

Osozawa, S., Morimoto, J., Flower, M.F.J., 2009. "Block-in-matrix" fabrics that lack shearing but possess composite cleavage planes: a sedimentary mélange origin for the Yuwan accretionary complex in the Ryukyu island arc, Japan. GSA Bulletin, 121: 1190-1203.

Oszczypko, N., 1992. Late Cretaceous through Paleogene evolution of Magura Basin. Geologica Carpathica, 43: 333-338.

Oszczypko, N., 1998. The Western Carpathians Foredeep - development of the foreland basin in front of the accretionary wedge and its burial history (Poland). Geologica Carpathica, 49: 415-431.

Oszczypko, N., 2004. The structural position and tectonosedimentary evolution of the Polish Outer Carpathians. Przegląd Geologiczny, 52: 780-791.

Oszczypko, N., 2006. Late Jurassic-Miocene evolution of the Outer Carpathian fold-and-thrust belt and its foredeep basin (Western Carpathians, Poland). Geological Quarterly, 50 (1): 169-194.

Oszczypko, N., Ślączka, A., 1987. Olistostromes and overthrusting in Polish Carpathians. Annales Instituti Geologici Publici Hungarici, 70: 282-292. 
Oszczypko, N., Malata, E., Bąk, K., Kędzierski, M., OszczypkoClowes, M., 2005. Lithostratigraphy and biostratigraphy of the Upper Albian-Lower/Middle Eocene flysch deposits in the Bystrica and Rača subunits of the Magura Nappe; Western Flysch Carpathians (Beskid Wyspowy and Gorce Ranges, Poland). Annales Societatis Geologorum Poloniae, 75: 27-69.

Oszczypko, N., Uchman, A., Malata, E., ed., 2006. Rozwój paleotektoniczny basenów Karpat zewnętrznych i pienińskiego pasa skałkowego (in Polish). Instytut Nauk Geologicznych Uniwersytetu Jagiellońskiego, Kraków.

Oszczypko, N., Ślączka, A., ytko, K., 2008. Tectonic subdivision of Poland: Polish Outher Carpathians and their foredeep (in Polish with English summary). Przegląd Geologiczny, 56: 927-935.

Oszczypko-Clowes, M., 2001. The nannofossils biostratigraphy of the youngest deposits of the Magura nappe (East of the Skawa river, Polish Flysch Carpathians) and their palaeoenvironmental conditions. Annales Societatis Geologorum Poloniae, 71 139-188.

Pazdro, Z., 1934. C.-R. des recherches géologiques exécuées en 1933 pour la feuille Brzostek-Strzy ów (in Polish with French summary). Posiedzenia Naukowe Państwowego Instytutu Geologicznego, 39: 13-14.

Pearson, P.N., Olsson, R.K., Huber, B.T., Hemleben, C. Berggren, W.A., ed., 2006. Atlas of Eocene Planktonic Foraminifera. Cushman Foundation Special Publication, 41.

Peryt, D., 2013. Foraminiferal record of the Middle Miocene climate transition prior the Badenian salinity crisis in the Polish Carpathian Foredeep Basin (Central Paratethys). Geological Quarterly, 57 (1): 141-164.

Pini, G.A., 1999. Tectonosomes and olistostromes in the Argille Scagliose of the Northern Apennines, Italy. GSA Special Paper, 335: 1-70.

Pini, G.A., Lucente, C.C., Cowan, D.S., De Libero, C.M., Dellisanti, F., Landuzzi, A., Negri, A., Tateo, F., Del Castello, M., Morrone, M., Cantelli, L., 2004. The role of olistostromes and argille scagliose in the structural evolution of the Northern Apennines. Memorie Descrittive della Carta Geologica d'Italia, 63: $1-40$.

Poltowicz, S., 1978. Gravity slides of the Flysch Carpathian Marginal Zone in the light of new global tectonics (in Polish with English summary). Rocznik Polskiego Towarzystwa Geologicznego, 48: 407-444.

Premoli Silva, I., Sliter, W.V., 2002. Practical manual of Cretaceous planktonic foraminifera. In: International School on Planktonic Foraminifera, 1 course: Cretaceous, Perugia 18-22 February 2002 (eds. I. Premoli Silva and R. Rettori). Dipartimento di Scienze della Terra, University of Perugia (Italy).

Raymond, L.A., 1984. Classification of mélanges. GSA Special Paper, 198: 7-20.

Sengör, A.M.C., 2003. The repeated rediscovery of mélanges and its implication for the possibility and the role of objective evidence in the scientific enterprise. GSA Special Paper, 373 385-445.

Sikora, W., 1964. Szczegółowa mapa geologiczna Polski w skali 1:50 000 (bez utworów czwartorzędowych), region Karpat Przedgórza, ark. Gorlice (in Polish). Wyd. Geol., Warszawa.

Sikora, W., 1970. Geology of the Magura nappe between Szymbark Ruski and Nawojowa (in Polish with English summary). Biuletyn Instytutu Geologicznego, 13: 5-121.

Sikora, W., 1976. Cordilleres of the Western Carpathians in the light of the plate tectonics theory (in Polish with English summary). Przegląd Geologiczny, 6: 336-349.

Sikora, W., Szymakowska, F., 1977. Problem IB - geneza płatów magurskich oraz rozwój facjalny brze nej strefy płaszczowiny magurskiej i utworów okna tektonicznego Ropy (in Polish).
Przewodnik 49 Zjazdu Polskiego Towarzystwa Geologicznego, Krosno: 88-105.

Silver, E.A., Beutner, E.C., 1980. Mélanges. Geology, 8: 32-34.

Słomka, T., 2001. Early Cretaceous debris flow deposits in the Cieszyn Beds of the ywiec region (Carpathians, Poland) (in Polish with English summary). Geologia, 27: 89-110.

Strzeboński, P., 2005. Cohesive debrites of the Istebna Beds (Upper Senonian-Paleocene) west of the Skawa River (in Polish with English summary). Geologia, 31: 201-224.

Szymakowska, F., 1966. Nowe stanowisko miocenu w Karpatach Środkowych (in Polish). Sprawozdanie z Posiedzenia Komisji Polskiej Akademii Nauk, Oddział w Krakowie I-VI 1966: 224-226.

Szymakowska, F., 1976. Olistostromes in the Krosno Beds (Polish Carpathians). Rocznik Polskiego Towarzystwa Geologicznego, 46: $39-45$.

Ślączka, A., 1961. Exotic-bearing shale from Bukowiec (Polish Eastern Carpathians) (in Polish with English summary). Rocznik Polskiego Towarzystwa Geologicznego, 31: 129-143.

Ślączka, A., Wieser, T., 1962. Shales with exotics in the Krosno beds of the Baligród region (Polish Eastern Carpathians) (in Polish with English summary). Kwartalnik Geologiczny, 6 (4): 662-677.

Ślączka, A., Renda, P., Cieszkowski, M., Golonka, J., Nigro, F., 2012. Sedimentary basins evolution and olistoliths formation: The case of Carpathian and Sicilian regions. Tectonophysics, 568-569: 306-319.

Świdziński, H., 1934. Remarques sur la structure des Karpates flyscheuses (in Polish with French summary). Sprawozdania Państwowego Instytutu Geologicznego, 8: 75-139.

Świdziński, H., 1953. Karpaty fliszowe między Dunajcem a Sanem (in Polish). Regionalna Geologia Polski t. 1/2, Karpaty. Polskie Towarzystwo Geologiczne, Kraków: 362-422.

Świdziński, H., 1958. Mapa Geologiczna Karpat Polskich (in Polish). Część wschodnia. Instytut Geologiczny, Warszawa.

Tołwiński, K., 1921. Dislocations transversales et directions tectoniques des Carpathes Polonaises (in Polish with French summary). Przegląd Geograficzny, 6: 27-47.

Wakabayashi, J., 2011. Mélanges of the Franciscan Complex, California: diverse structural setting, evidence for sedimentary mixing, and their connection to subduction processes. GSA Special Paper, 480: 117-142.

Wakabayashi, J., Dilek, Y., 2011. Introduction: characteristics and tectonic settings of mélanges, and their significance for societal and engineering problems. GSA Special Paper, 480: 5-10.

Wójcik, A., Jasionowicz, J., Szymakowska, F., 1992. Szczegółowa mapa geologiczna Polski w skali 1:50 000, ark. Jasło (in Polish). Wyd. Geol., Warszawa.

Yamamoto, Y., Tonogai, K., Anma, R., 2012. Fabric-based criteria to distinguish tectonic from sedimentary mélanges in the Shimanto accretionary complex, Yakushima Island, SW Japan. Tectonophysics, 568-569: 65-73.

Zuchiewicz, W., Oszczypko, N., 2008. Topography of the Magura floor thrust and morphotectonics of the Outer West Carpathians in Poland. Annales Societatis Geologorum Poloniae, 78 135-149.

elaźniewicz, A., Aleksandrowski, P., Buła, Z., Karnkowski, P.H., Konon, A., Oszczypko, N., Ślączka, A., aba, J., ytko, K., 2011. Regionalizacja tektoniczna Polski. Komitet Nauk Geologicznych PAN, Wrocław: 39-51.

ytko, K., Gucik, S., Ryłko, W., Oszczypko, N., Zając, R., Garlicka, I., Nemčok, J., Eliáš, M., Dvořák, J., Stránik, Z., Rakus, O., Matějovska, O., 1989. Geological Map of the Western Outer Carpathians and their Foreland without Quaternary formations. NAG, PGI-NRI, Warszawa. 